http://kitaibelia.unideb.hu/

ISSN 2064-4507 (Online) • ISSN 1219-9672 (Print)

(C) 2017, Department of Botany, University of Debrecen, Hungary

22 (1): 179-220.; 2017

DOI: $10.17542 /$ kit.22.179

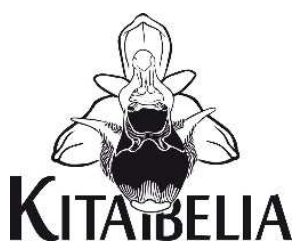

\title{
A Nyírség tölgy-kőris-szil ligetei (Fraxino pannonicae-Ulmetum Soó in Aszód 1935 corr. Soó 1963)
}

\author{
KEVEY Balázs ${ }^{1}$, PAPP László ${ }^{2}$ \& LENDVAI Gábor ${ }^{3}$
}

(1) Pécsi Tudományegyetem, Ökológiai Tanszék, H-7624 Pécs, Ifjúság u. 6.; keveyb@ttk.pte.hu

(2) Debreceni Egyetemi, Botanikus kert, H-4032 Debrecen, Egyetem tér 1.

(3) H-7000 Sárbogárd, Ady E. u. 162.

\section{Oak-ash-elm forests in the Nyírség}

\begin{abstract}
This paper presents phytosociological analyses of oak-ash-elm forests of Nyírség, NE Hungary. These climatically azonal forests grow in habitats where the soil is under the continual influence of the groundwater table, which maintains rather mesic conditions. They are particularly rich in Fagetalia elements (Actaea spicata, Allium ursinum, Anemone ranunculoides, Asarum europaeum, Athyrium filix-femina, Cardamine bulbifera, Carex pilosa, Cerastium sylvaticum, Chaerophyllum aromaticum, Corydalis cava, Dryopteris filix-mas, Epipactis helleborine agg., Euphorbia amygdaloides, Galeobdolon luteum, Galium odoratum, Hedera helix, Isopyrum thalictroides, Lathraea squamaria, Lathyrus vernus, Lilium martagon, Majanthemum bifolium, Mercurialis perennis, Milium effusum, Polygonatum multiflorum, Pulmonaria officinalis, Ranunculus cassubicus, Salvia glutinosa, Sanicula europaea, Scilla vindobonensis, Stachys sylvatica, Stellaria holostea etc.) typical in the submontane regions of this part of Europe. It is possible that they are remnants of the vegetation dominating the region under the less continental and more moist climate during the Beech phase (2500-800 BC) of the Holocene.
\end{abstract}

Keywords: Hungarian Plain, multivariate analyses, nature reserve, phytosociology

Összefoglalás - Jelen tanulmány Magyarország keleti részén, a Nyírség tölgy-kőris-szil ligeterdeinek társulási viszonyait mutatja be 75 cönológiai felvétel alapján. Mérsékelten talajvíz által befolyásolt, azonális asszociációval állunk szemben. Állományaikban feltűnőek egyes szubmontán elemek, amelyek az Alföldön általában ritkák. Különösen a Fagetalia elemek gyakorisága jellemző: Actaea spicata, Allium ursinum, Anemone ranunculoides, Asarum europaeum, Athyrium filix-femina, Cardamine bulbifera, Carex pilosa, Cerastium sylvaticum, Chaerophyllum aromaticum, Corydalis cava, Corydalis solida, Dryopteris filix-mas, Epipactis helleborine agg., Euphorbia amygdaloides, Galeobdolon luteum, Galium odoratum, Hedera helix, Isopyrum thalictroides, Lathraea squamaria, Lathyrus vernus, Lilium martagon, Maianthemum bifolium, Mercurialis perennis, Milium effusum, Polygonatum multiflorum, Pulmonaria officinalis, Ranunculus cassubicus, Salvia glutinosa, Sanicula europaea, Scilla vindobonensis, Stachys sylvatica, Stellaria holostea stb. E növények főleg a Nyírség keleti részén fordulnak elő, s valószínűleg az egykori hűvösebb, csapadékosabb és kiegyenlítettebb klímájú „Bükk I. kor” (i.e. 2500-tól i.e. 800-ig) maradványfajai.

Kulcsszavak: fitocönológia, Magyar Alföld, természetvédelmi terület, többváltozós adatelemzés 


\section{Bevezetés}

A Nyírség tölgy-kőris-szil ligeterdeiről Soó (Soó in AszóD 1935, Soó 1937, 1938, 1943, 1953) közölte az első cönológiai adatokat. Először egy szintetikus táblázat (Soó in AszóD 1935), majd egy 23 felvételt tartalmazó részletes táblázat (Soó 1943) jelent meg. E felvételek Bátorligetnél a „Veres-folyás” patak mentén és a „Fényi-erdő”-ben, valamint a Debrecen melletti „Halápi-erdő”-ben készültek. Közülük húsz kvadrát $25 \mathrm{~m}^{2}$-es területű, míg két felvétel $50 \mathrm{~m}^{2}$ es, egyikük pedig $100 \mathrm{~m}^{2}$-es. Legutóbb PAPP et al. (1986) közölt cönológiai adatokat a Bátorliget melletti „Fényi-erdő”-ből.

Kevey Balázs 1979-ben kezdte az egyre pusztuló nyírségi tölgy-kőris-szil ligetek részletes felmérését, s Bátorliget és Terem közelében számos felvételt készített. Később megismerkedett a Nyírség növényvilágának kitűnő ismerőjével, Papp Lászlóval. Ezután a Nyírség erdeinek cönológiai felmérését együtt végeztük, miközben Lendvai Gábor is bekapcsolódott a felmérésekbe. E munka eredményeként a tölgy-kőris-szil ligetekből 80 cönológiai felvétel készült, amelyekből 75 felvételt (25 felv.: Ny-Nyírség; 50 felv.: K-Nyírség) közlünk e tanulmányban. Felméréseinket etalonként bocsátjuk a jövő számára, amely bizonyítja, hogy milyenek voltak a Nyírség tölgy-kőris-szil ligeterdei az ezredforduló tájékán.

\section{Anyag és módszer}

\section{Kutatási terület jellemzése}

A Nyírség Magyarország keleti részének homokvidéke, amely Nyírségense néven önálló flórajárásnak tekinthető (vö. Soó 1960). A természetes vegetációból kevés erdő érte meg a jelenkort. Az ilyen még természetszerűnek mondható tölgy-kőris-szil ligeterdőkben készítettük a cönológiai felvételeket. Mivel a felmérések alatt úgy láttuk, hogy a Nyírség nyugati és keleti részének ligeterdei között némi különbség van, ezért felvételeinket két külön táblázatba helyeztük. Ennek megfelelően a Nyírség szárazabb nyugati és délnyugati peremét neveztük Nyugati-Nyírségnek (Újfehértó, Téglás, Debrecen, Józsa, Nagycsere, Haláp, Nyíradony és Nyírábrány térsége). A Nyírség keleti része már kissé üdébbnek tűnik (Ófehértó, Baktalórántháza, Nyírvasvári, Bátorliget, Terem, Mérk és Vállaj térsége), ezért ezt tekintettük Keleti-Nyírségnek.

\section{Alkalmazott módszerek}

A cönológiai felvételeket a Zürich-Montpellier növénycönológiai iskola (BECKING 1957, BRAUN-BLANQUET 1964) hagyományos kvadrát-módszerével készítettük. A felvételek táblázatos összeállítását, valamint a karakterfajok csoportrészesedését és csoporttömegét az „NS” számítógépes programcsomag (KEVEY \& HIRMANN 2002) segítségével végeztük. A felvételkészítés és a hagyományos statisztikai számítások módszerét KEVEY (2008) korábban részletesen közölte. A felvételek összehasonlításánál - a SYN-TAX 2000 programcsomag (PoDANI 2001) segítségével - bináris cluster-analízist (hasonlósági index: Baroni-Urbani-Buser; fúziós algoritmus: összetett lánc) és ugyancsak bináris ordinációt végeztünk (hasonlósági index: Baroni-Urbani-Buser; fúziós algoritmus: főkoordináta-analízis). A fajok esetében KIRÁLY (2009), a társulásoknál pedig az újabb hazai nómenklatúrát (BoRHIDI \& KEVEY 1996, KEVEY 2008, BoRHIDI et al. 2012) követjük. A társulástani és a karakterfaj-statisztikai táblázatok felépítése az újabb eredményekkel (OBERDORFER 1992, MuCinA et al. 1993, KEVEY 2008, BorHIDI et al. 2012) módosított Soó (1980) féle cönológiai rendszerre épül. A növények cönoszisztematikai besorolásánál is elsősorban Soó $(1964,1966,1968,1970,1973,1980)$ Synopsis-ára támaszkodtunk, de figyelembe vettük az újabb kutatási eredményeket is (vö. BORHIDI 1993, 1995, HORVÁTH et al. 1995, KEVEY 2008). 


\section{Eredmények}

Termőhelyi viszonyok, zonalitás

BoRHIDI (1961) klímazonális térképe szerint a Nyírség a zárt tölgyes zónába tartozik, amelyet e tájon a gyöngyvirágos-tölgyes (Convallario-Quercetum roboris) képvisel. A homoktáblákat átszelő patakok mentén és olyan helyeken, ahol a talajvízszint viszonylag közel van a felszínhez, e gyöngyvirágos-tölgyeseket azonális tölgy-kőris-szil ligetek (Fraxino pannonicaeUlmetum) váltják fel. A két asszociáció ma is több helyen érintkezik és szukcessziós kapcsolatban van egymással. Ez úgy értendő, hogy azon ligeterdő állományok, amelyeknél a talajvízszint mélyebbre kerül, fokozatosan gyöngyvirágos-tölgyesekké fejlődnek (KEVEY 2008).

A felvételezett állományok 116-150 m tengerszint feletti magasság mellett találhatók. Síkvidék lévén az égtáji kitettség és a lejtőszög e társulás kialakulásában nem játszik szerepet. Az alapkőzetet homok képezi, amelynek felső rétege a legtöbb helyen barna erdőtalajszerű öntés erdőtalajjá fejlődött. E talajok a félnedves és üde vízgazdálkodási fokozatba sorolhatók. A tájat átszelő vízfolyások viszonylag magasabb talajvízszintet, valamint üde, párás és hűvös mikroklímát biztosítanak.

\section{Fiziognómia}

A vizsgált tölgy-kőris-szil ligetek felső lombkoronaszintje az állomány korától függően 20-32 m magas, közepesen, vagy jól záródó (50-80\%). Állandó fajai (K: IV-V) a Ny-Nyírségben csak a Quercus robur, míg a K-Nyírségben a Quercus robur mellett a Fraxinus angustifolia is előtérbe kerül. A Nyírség mindkét részén jelentős borítást (A-D: 3-5) ér el a Fraxinus angustifolia, a Populus alba és a Quercus robur. A K-Nyírségben e fák mellett az Acer campestre, a Tilia cordata, a Tilia tomentosa és az Ulmus laevis is előfordul ilyen tömegben. Az alsó lombkoronaszint változóan fejlett. Magassága 10-20 m, borítása pedig 5-50\%. Főleg alászorult fák alkotják. Állandó fajai (K: V) a Ny-Nyírségben az Ulmus minor, a K-nyírségben pedig az Acer campestre és az Ulmus laevis. Nagyobb tömeget (A-D: 3-4) mindkét tájegységen az Acer campestre, a Ny-Nyírségben a Tilia tomentosa, az Ulmus laevis és az Ulmus minor, a KNyírségben pedig a Fraxinus angustifolia ér el.

A cserjeszint ugyancsak változóan fejlett, amely nagyrészt az erdészeti beavatkozásokkal kapcsolatos. Magassága 1,5-5 m, borítása pedig 10-80\%. Állandó elemei (K: IV-V) a Nyírség mindkét felén a Corylus avellana, a Crataegus monogyna és az Ulmus minor. Mellettük a NyNyírségben előtérbe kerül a Ligustrum vulgare és a Sambucus nigra, a K-Nyírségben pedig az Acer campestre, a Cornus sanguinea és a Fraxinus angustifolia. Nagyobb tömeget (A-D: 3-4) a Nyírség mindkét felén az Acer campestre, a Corylus avellana és a Crataegus monogyna ér el. A K-Nyírségben e szerepet még egyéb fajok is betöltik: Cornus mas, Cornus sanguinea, Sambucus nigra és ritkán a Staphylea pinnata. Az alsó cserjeszint (újulat) borítása igen változó (1-70\%). Állandó fajai (K: IV-V) mindkét tájegységnél a következők: Cornus sanguinea, Corylus avellana, Crataegus monogyna, Euonymus europaea, Ligustrum vulgare, Quercus robur, Rubus caesius, Ulmus minor, Viburnum opulus. Ilyen állandóságot mutat a NyNyírségben még a Sambucus nigra, a K-Nyírségben pedig az Acer campestre és a Fraxinus angustifolia. Nagyobb tömeget (A-D: 3-4) e szintben a Nyírség mindkét felén csak a Hedera helix ér el.

A gyepszint borítása is változó (15-100 \%). Állandó elemei (K: IV-V) a Nyírség mindkét tájegységén a következők: Alliaria petiolata, Brachypodium sylvaticum, Chaerophyllum temulum, Circaea lutetiana, Convallaria majalis, Galium aparine, Geranium robertianum, Geum urbanum, Lapsana communis, Moehringia trinervia, Stachys sylvatica, Urtica dioica. Ilyen állandóságot mutat a Nyugat-Nyírségben még hét faj (Arctium minus, Cucubalus baccifer, 
Dactylis polygama, Elymus caninus, Festuca gigantea, Galeopsis pubescens, Polygonatum latifolium, Veronica sublobata), a Kelet-Nyírségben pedig még kilenc faj (Ajuga reptans, Carex remota, Polygonatum multiflorum, Milium effusum, Pulmonaria officinalis, Ranunculus ficaria, Scrophularia nodosa, Torilis japonica, Viola reichenbachiana). Fáciest (A-D: 3-5) a Nyírség mindkét részén az Aegopodium podagraria, a Cardamine bulbifera, a Convallaria majalis és a Ranunculus ficaria képez. E szerepet a Ny-Nyírségben a Chaerophyllum temulum, a Corydalis cava, az Impatiens parviflora, a Polygonatum latifolium, a Salvia glutinosa és a Vinca minor, a K-Nyírségben pedig az Allium ursinum, a Circaea lutetiana, az Equisetum hyemale és az Impetiens noli-tangere is betölti.

Fajkombináció

\section{Állandósági osztályok}

A 25 és 50 cönológiai felvétel alapján az állandósági osztályok terén a legkisebb fajszám a szubkonstans (K IV) elemeknél van, míg az akcidens (K I) fajok mellett a konstans (K V) fajoknál jelentkezik egy második maximum. A konstancia osztályok fajszáma mind a Nyugati-, mind pedig a Keleti-Nyírség esetében hasonló (1. ábra A). Mindkét tájegységnél állandó (K IV-V) fajok a következők: Alliaria petiolata, Brachypodium sylvaticum, Chaerophyllum temulum, Circaea lutetiana, Convallaria majalis, Cornus sanguinea, Corylus avellana, Crataegus monogyna, Euonymus europaeus, Galium aparine, Geranium robertianum, Geum urbanum, Lapsana communis, Ligustrum vulgare, Quercus robur, Rubus caesius, Sambucus nigra, Stachys sylvatica, Ulmus minor, Urtica dioica, Viburnum opulus. Vannak fajok, amelyek csak a NyugatiNyírség tölgy-kőris-szil ligeteiben állandóak (K IV-V): Arctium minus, Cerasus avium, Cucubalus baccifer, Dactylis polygama, Elymus caninus, Festuca gigantea, Galeopsis pubescens, Polygonatum latifolium, Veronica sublobata. Más fajok csak a Keleti-Nyírség tölgy-kőris-szil ligeteiben mutatnak nagy állandóságot (K IV-V): Acer campestre, Acer tataricum, Ajuga reptans, Carex remota, Fraxinus angustifolia, Milium effusum, Moehringia trinervia, Polygonatum multiflorum, Pulmonaria officinalis, Ranunculus ficaria, Scrophularia nodosa, Torilis japonica, Ulmus laevis, Viola reichenbachiana.

\section{Karakterfajok aránya}

A Nyírség tölgy-kőris-szil ligetei sok szubmontán (Fagetalia) elem számára nyújtanak menedéket. Arányuk a Nyírség keleti felén mintegy kétszer akkora, mint a nyugati felén (5. táblázat, 1. ábra B). Ilyen Fagetalia jellegű fajok a következők1: Acer platanoides (II, I), Acer pseudo-platanus (I, I), Actaea spicata (-, III), Aegopodium podagraria (I, III), Allium ursinum (-, III), Anemone ranunculoides (I, III), Arum orientale (II, -), Asarum europaeum (-, I), Athyrium filixfemina (I, I), Cardamine bulbifera (I, II), Carex pilosa (-, I), Carex sylvatica (III, III), Carpinus betulus (-, III), Cerastium sylvaticum (-, I), Cerasus avium (IV, II), Chaerophyllum aromaticum (-, I), Circaea lutetiana (V, V), Corydalis cava (II, I), Corydalis solida (I, -), Dryopteris filix-mas (-, II), Epipactis helleborine agg. (incl. Epipactis tallósii) (II, III), Euphorbia amygdaloides (-, II), Galeobdolon luteum (-, II), Galium odoratum (I, II), Glechoma hirsuta (II, -), Hedera helix (I, III), Isopyrum thalictroides (-, I), Lathraea squamaria (-, II), Lathyrus vernus (-, I), Lilium martagon (I, II), Listera ovata (I, III), Maianthemum bifolium (-, II), Mercurialis perennis (-, I), Milium effusum (II, IV), Moehringia trinervia (IV, V), Myosotis sparsiflora (I, -), Paris quadrifolia (-, II), Polygonatum multiflorum (III, V), Pulmonaria officinalis (I, IV), Ranunculus cassubicus (-, I), Ribes uva-crispa (I, -), Salvia glutinosa (III, I), Sanicula europaea (I, II), Scilla vindobonensis (II, II), Stachys sylvatica (V, IV), Stellaria holostea (-, I), Ulmus glabra (-, I), Vinca minor (I, -), Viola reichenbachiana (I, V) (1. és 3. táblázat).

${ }^{1}$ A zárójelben levő K-értékek közül az első a Nyírség nyugati, a második a keleti felére vonatkozik. 

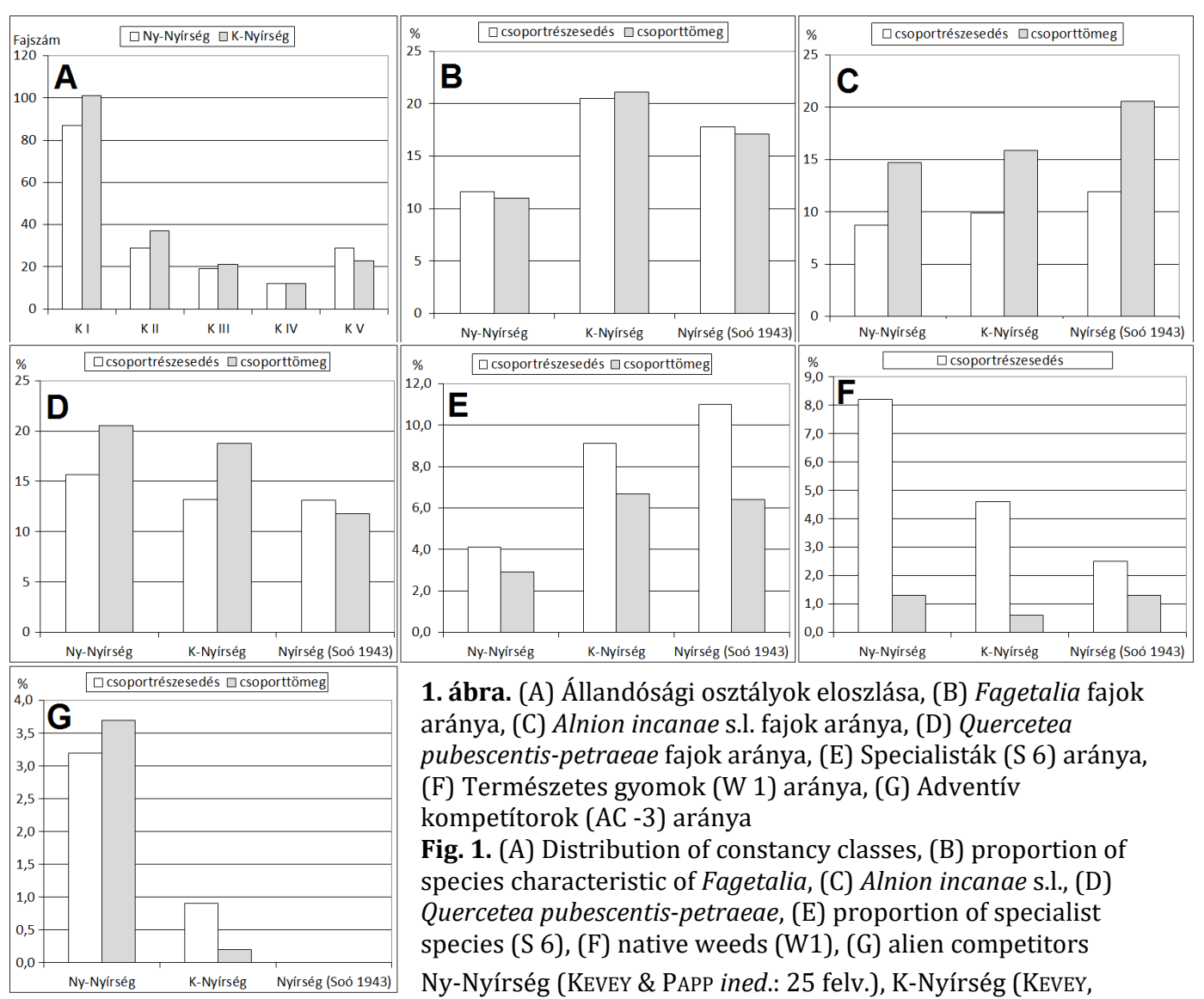

1. ábra. (A) Állandósági osztályok eloszlása, (B) Fagetalia fajok aránya, (C) Alnion incanae s.l. fajok aránya, (D) Quercetea pubescentis-petraeae fajok aránya, (E) Specialisták (S 6) aránya, (F) Természetes gyomok (W 1) aránya, (G) Adventív kompetítorok (AC -3) aránya

Fig. 1. (A) Distribution of constancy classes, (B) proportion of species characteristic of Fagetalia, (C) Alnion incanae s.l., (D) Quercetea pubescentis-petraeae, (E) proportion of specialist species (S 6), (F) native weeds (W1), (G) alien competitors Ny-Nyírség (Kevey \& PAPP ined.: 25 felv.), K-Nyírség (KeveY, LENDVAI \& PAPP ined.: 50 felv.), Nyírség (Soó 1943: 23 felv.)

Jelentősek a keményfaligeti (Alnion incanae) elemek is. Ezek aránya a Nyírség keleti felén valamivel nagyobb, mint a nyugati felén, míg Soó (1943) felvételeiben a jelenleginél lényegesen magasabb arányt mutatnak (5. táblázat, 1. ábra C). Ilyen jellegű fajok a következők: Carex brizoides (I, I), Carex remota (II, IV), Dipsacus pilosus (I, -), Elymus caninus (V, II), Equisetum hyemale (I, I), Festuca gigantea (IV, III), Frangula alnus (I, II), Fraxinus angustifolia ssp. danubialis (III, V), Impatiens noli-tangere (-, I), Malus sylvestris (II, II), Oenanthe banatica (-, I), Padus avium (I, I), Populus alba (II, III), Ribes rubrum (I, I), Rumex sanguineus (II, II), Ulmus laevis (III, V), Ulmus minor (V, V), Viburnum opulus (IV, IV) (1. és 3. táblázat).

Szórványosan megjelennek a száraz tölgyesek (Quercetea pubescentis-petraeae) egyes növényei is. Ezek a Nyírség nyugati felén valamivel magasabb arányt érnek el, mint a keleti felén, míg Soó (1943) felvételei szerint mutatják a legkisebb értéket (5. táblázat, 1. ábra D). Fontosabbak a következők: Acer tataricum (I, IV), Allium oleraceum (I, I), Astragalus glycyphyllos (I, I), Betonica officinalis (I, I), Carex michelii (I, -), Clematis recta (I, I), Clinopodium vulgare (I, I), Cornus mas (I, I), Euonymus verrucosus (I, I), Gagea pratensis (III, I), Hylotelephium telephium ssp. maximum (I, I), Lactuca quercina ssp. quercina (I, -), Lactuca quercina ssp. sagittata (II, -), Melica picta (I, I), Melittis melissophyllum ssp. carpatica (I, I), Physalis alkekengi (I, I), Polygonatum odoratum (I, -), Prunus spinosa (III, II), Pulmonaria mollissima (II, I), Pyrus pyraster (III, II), Quercus cerris (I, I), Rosa canina agg. (I, I), Vincetoxicum hirundinaria (I, -) (1. és 3. táblázat). 


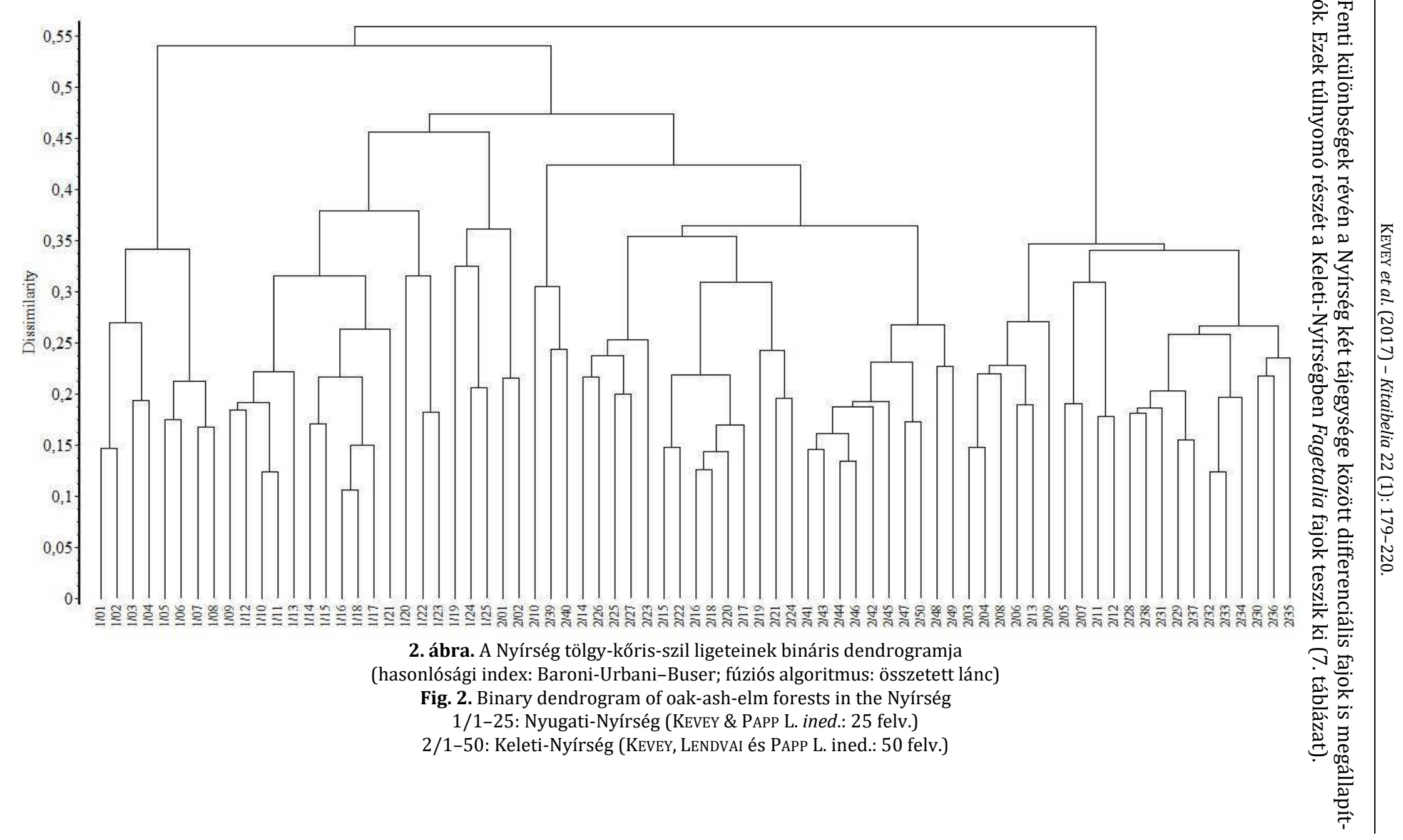




\section{Szociális magatartási típusok aránya}

A BoRHIDI $(1993,1995)$ féle szociális magatartási típusok aránya terén legfeltűnőbb az, hogy a specialisták (S 6) aránya a Nyírség keleti felén több mint kétszer annyi, mint a nyugati felén (6. táblázat, 1. ábra E). Az egyes degradációt jelző fajok esetében ezzel ellentétes tendencia figyelhető meg. Így a természetes gyomok (W 1) és az adventív kompetítorok (A -3) aránya a Nyírség keleti felén sokkal alacsonyabb, míg Soó (1943) felvételei alapján ez az arány a legkisebb.

\section{Sokváltozós elemzések eredményei}

Ha a Nyírség tölgy-kőris-szil ligeteiből készített 75 felvételt bináris cluster-analízissel (8. ábra) és ordinációval (9. ábra) megvizsgáljuk, azt tapasztaljuk, hogy a Nyírség nyugati és keleti részéről készült felvételek többé-kevésbé két csoportba rendeződnek. Az elkülönülés azonban nem teljes, ugyanis az átmeneti zónában mindkét tájegység felvételei keverednek.

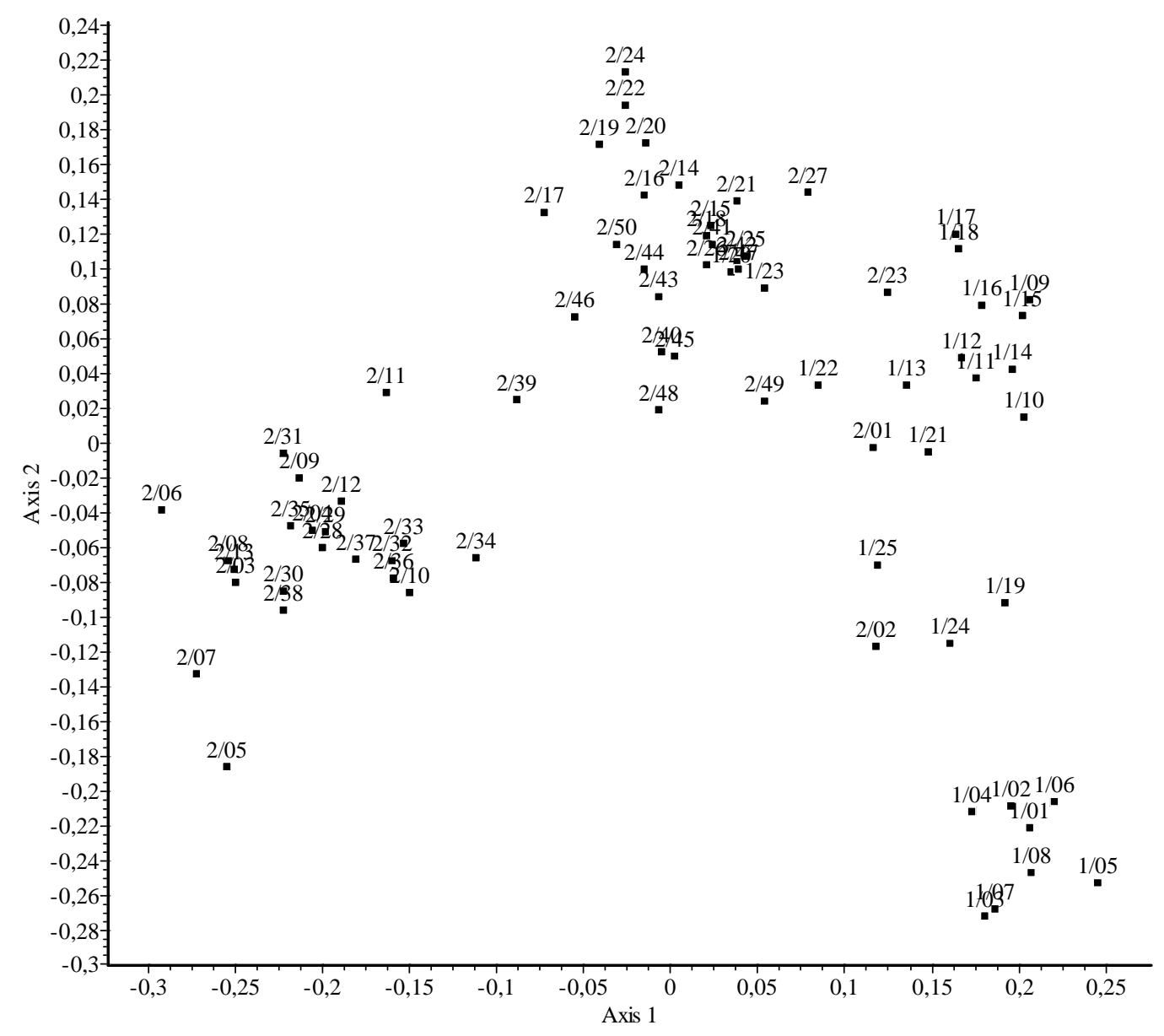

3. ábra. A Nyírség tölgy-kőris-szil ligeteinek bináris ordinációs diagramja (hasonlósági index: Baroni-Urbani-Buser; fúziós algoritmus: főkoordináta-analízis)

Fig. 3. Binary ordination diagram of oak-ash-elm forests in the Nyírség 1/1-25: Nyugati-Nyírség (Kevey \& PAPP ined.: 25 felv.)

2/1-50: Keleti-Nyírség (KEVEY, LendVAI \& PAPP ined.: 50 felv.) 


\section{Megvitatás}

A Nyírség tölgy-kőris-szil ligeterdeinek felmérésekor már szembetűnt, hogy a keleti részén levő állományok tipikusabbak, mint a nyugatiak. A két tájon készült felvételi anyag összehasonlításakor kiderült, hogy a keleti részen mintegy kétszeres a Fagetalia fajok aránya (1. ábra B), valamivel magasabb értéket érnek el az Alnion incanae s.l. elemek (1. ábra C), a Quercetea pubescentis-petraeae jellegű fajok (1. ábra D) viszont kisebb szerepet töltenek be, mint a nyugati részen. Ennek egyrészt éghajlattani magyarázata van. Debrecen az erdőssztyep és a zárt tölgyes zóna határán fekszik (vö. BoRHIDI 1961), ahol szárazabb és kontinentálisabb a klíma, mint a Nyírség keleti részén. Másrészt a táj nyugati peremén a lecsapolások sokkal jobban átalakították a talajvíz viszonyokat, mint keleten, ezért az erdők gyepszintjében is némileg visszaszorulhattak a mezofil Fagetalia és a higrofil Alnion incanae elemek, míg egyes Quercetea jellegű fajok jobban tért hódíthattak. E kettősség a BoRHIDI $(1993,1995)$ féle szociális magatartási típusokon is megmutatkozik. Így a specialisták aránya (1. ábra E) nyugaton lényegesen alacsonyabb, mint keleten. A degradációt jelző fajok esetében viszont ezzel ellentétes tendencia mutatkozik: a természetes gyomok (1. ábra F) és az adventív kompetítorok (1. ábra G) a Nyírség nyugati részének ligeterdeiben sokkal gyakoribbak, mint a keleti állományokban. Ebből a nyugati tölgy-kőris-szil ligetek lényegesen nagyobb degradációjára lehet következtetni (6. táblázat).

Az elemzésekbe bevontuk Soó (1943) felvételeit is. Bár ő lényegesen kisebb kvadrátokkal (általában $25 \mathrm{~m} 2$ ) dolgozott, mégis úgy láttuk, hogy egyes szüntaxonok és szociális magatartási típusok arányainak kimutatására e felvételek felhasználhatók. E téren úgy látszik, hogy a mintegy 80 évvel ezelőtti nyírségi erdőkben magasabb volt az Alnion incanae (1. ábra C) és alacsonyabb a Quercetea (1. ábra D) jellegű fajok aránya, s továbbá a degradáció is jóval kisebb mértékű volt a jelenleginél. Ennek bizonyítéka, hogy a specialisták (1. ábra E) aránya magasabb, a természetes gyomok (1. ábra F) és az adventív kompetítorok (1. ábra G) aránya viszont jóval alacsonyabb volt.

A sokváltozós elemzések eredményei szerint a Nyírség nyugati és keleti részének tölgykőris-szil ligetei ugyan kissé elkülönülnek, de közöttük a hasonlóság oly mértékű, hogy mindkét táj állományait a Fraxino pannonicae-Ulmetum asszociációba sorolhatjuk. Tipikusnak a Keleti-Nyírség erdeit tekinthetjük, míg a Nyugati-Nyírség állományait e társulás kissé elszegényedett változataként értelmezhetjük. Az asszociáció helye a szüntaxonómiai rendszerben az alábbi módon vázolható:

Divisio: Q U E R C O - F A G E A JAKUCS 1967

Classis: QUERCO-FAGETEA BR.-BL. et VLIEgER in VLIEgER 1937 em. BORHIDI in BORHIDI et KEVEY 1996

Ordo: FAGETALIA SYLVATICAE PAWŁOWSKI in PAWŁOWSKI et al. 1928

Alliance: Alnion incanae PAWŁOWSKI in PAWŁOWSKI et al. 1928

Suballiance: UImenion OBERDORFER 1953

Associatio: Fraxino pannonicae-Ulmetum Soó in Aszód 1935 corr. Soó 1963

\section{Természetvédelmi vonatkozások}

A Nyírség tölgy-kőris-szil ligeteiben sok hegyvidéki növényfaj talál menedéket. Szubmontán fajai (pl. Actaea spicata, Allium ursinum, Anemone ranunculoides, Asarum europaeum, Corydalis cava, Corydalis solida, Euphorbia amygdaloides, Galeobdolon luteum, Isopyrum thalictroides, Lilium martagon, Maianthemum bifolium, Mercurialis perennis, Milium effusum, Sanicula europaea, Stellaria holostea stb.) részben folyók mentén levándorolt elemek, rész- 
ben pedig az i.e. 2500-tól i.e. 800-ig tartó „Bükk I. kor” maradványfajai (vö. ZóLYomi 1936, 1952; JÁRAI-KoMLÓDI, M. 1966a, 1966b, 1968). Így e tölgy-kőris-szil ligetek flóra- és vegetációtörténeti szempontból is jelentősek.

A vizsgált állományokból 15 védett növényfaj került elö, amelyek tovább növelik a társulás természetvédelmi értékét: Dryopteris carthusiana (I, I), Cephalanthera damasonium (I, -), Epipactis helleborine (incl. E. tallosii) (II, III), Equisetum hyemale (I, I), Leucojum aestivum (-, I), Lilium martagon (I, II), Listera ovata (I, III), Neottia nidus-avis (-, I), Ophioglossum vulgatum (I, -), Platanthera bifolia (-, I), Platanthera chlorantha (-, I), Polystichum aculeatum (-, I), Scilla vindobonensis (-, II), Trollius europaeus (I, -), Veratrum album (I, II).

A dendrológiai értékek között említhetők egyes hatalmas méretű fák, amelyek törzsátmérője gyakran a két métert is eléri. Túlnyomó részük Quercus robur, ritkábban Ulmus laevis. Figyelemre méltók továbbá a fává nőtt cserjék, mint a Cornus sanguinea, Crataegus monogya és a Corylus avellana.

Flóraszennyező hatást fejtenek ki egyes tájidegen növények: Acer negundo (III, I), Ailanthus altissima (I, I), Celtis occidentalis (III, I), Deutzia scabra (I, -), Fraxinus pennsylvanica (I, I), Gleditsia triacanthos (I, -), Impatiens parviflora (II, I), Juglans nigra (I, I), Juglans regia (I, I), Padus serotina (II, I), Parthenocissus inserta (I, I), Phytolacca americana (I, -), Quercus rubra (I, I), Robinia pseudo-acacia (II, II), Stenactis annua (I, I), Vitis riparia (I, -).

A Nyírség ma még meglevő tölgy-kőris-szil ligeteinek nagyobb része valamilyen védelemben részesült (8. táblázat). Több erdő a Hajdúsági Tájvédelmi Körzet részét képezi: Debrecen „Halápi-erdő”, „Nagycsere”; Nyíradony „Gúti-erdő”; Nyírábrány „Kiskőrises”, „Mogyorósi-erdő". Van közöttük országos jelentőségú természetvédelmi terület: Bátorliget „Fényi-erdo”, „Veres-folyás”; Debrecen „Nagy-erdő”. Egyesek fokozott védelem alá is kerültek: Bátorliget „Fényi-erdő", „Veres-folyás”; Debrecen „Halápi-erdo”. Több erdő a Natura 2000 hálózat részét képezi: Bátorliget „Fényi-erdő", „Veres-folyás”; Debrecen „Nagy-erdő”, „Monostori-erdő”; Nyíradony „Gúti-erdő”; Nyírábrány „Mogyorósi-erdő”; Terem „Nagyfenék”. Helyi jelentőségú védelemben részesült a Debrecen melletti „Monostori-erdő”. Végül semmilyen oltalmat sem kapott a Mérk melletti „Vadas-kert”, a Nyírvasvári alatti „Csonkás-erdő" és az Újfehértó és Téglás közötti „Ángliusi-erdő”. Véleményünk szerint a mérki „Vadas-kert”, a Terem melletti „Nagyfenék” és a nyírábrányi „Mogyorós-erdő” fokozott védelmet érdemelne.

Mivel e társulás az Alföldön igen megfogyatkozott, örvendetes, hogy a Nyírségben még mindig vannak fajgazdag állományai. Sajnos ma már csak a felsorolt 13 erdőben találhatók természetközeli tölgy-kőris-szil ligetek, amelyek a kultúrerdők rengetegében szinte oázisként rejtőznek. Megőrzésük, helyenkénti rekonstrukciójuk természetvédelmünk fontos feladata.

\section{Köszönetnyilvánítás}

Köszönetünk illeti azon kollégákat, akik segítették munkánkat: Aradi Csaba, Bartha Dénes, ifj. Papp László.

\section{Rövidítések}

A1: felső lombkoronaszint; A2: alsó lombkoronaszint; Agi: Alnenion glutinosae-incanae; Ai: Alnion incanae; APa: Abieti-Piceea; AQ: Aceri tatarici-Quercion; Ar: Artemisietea; AR: Agropyro-Rumicion crispi; Ara: Arrhenatheretea; Arn: Arrhenatherion elatioris; Ate: Alnetea glutinosae; B1: cserjeszint; B2: újulat; Ber: Berberidion; Bia: Bidentetea; C: gyepszint; Cal: Calystegion sepium; Cau: Caucalidion platycarpos; Cgr: Caricenion gracilis; Che: Chenopodietea; ChS: Chenopodio-Scleranthea; Cp: Carpinenion betuli; Des: Deschampsion caespitosae; Epa: Epilobietea angustifolii; Epn: Epilobion angustifolii; EuF: Eu-Fagenion; F: 
Fagetalia sylvaticae; FBt: Festuco-Brometea; FiC: Filipendulo-Cirsion oleracei; FPi: FestucoPuccinellietalia; Fru: Festucion rupicolae; Fvl: Festucetalia valesiacae; GA: Galio-Alliarion; GU: Galio-Urticetea; incl.: inclusive (beleértve); ined.: ineditum (kiadatlan közlés); Mag: Magnocaricetalia; Moa: Molinietalia coeruleae; MoA: Molinio-Arrhenatherea; MoJ: MolinioJuncetea; Mon: Molinion coeruleae; NC: Nardo-Callunetea; Nc: Nanocyperion flavescentis; OCn: Orno-Cotinion; Onn: Onopordion acanthii; Pla: Plantaginetea; Pna: Populenion nigro-albae; PQ: Pino-Quercetalia; Prf: Prunion fruticosae; Pru: Prunetalia spinosae; Pte: Phragmitetea; Qc: Quercetalia cerridis; Qfa: Quercion farnetto; QFt: Querco-Fagetea; Qpp: Quercetea pubescentispetraeae; Qr: Quercetalia roboris; S: summa (összeg); Sal: Salicion albae; SCn: ScheuchzerioCaricetea nigrae; Sea: Secalietea; s.l.: sensu lato (tágabb értelemben); Spu: Salicetea purpureae; TA: Tilio platyphyllae-Acerenion pseudoplatani; Ulm: Ulmenion; US: UrticoSambucetea; VP: Vaccinio-Piceetea.

\section{Irodalom}

AszóD L. (1935): Adatok a nyírségi homoki vegetáció ökológiájához és szociológiájához. - Tisia 1 (1): 1-33. BECKING R. W. (1957): The Zürich-Montpellier Schol of phytosociology. - Botanical Review 23: 411-488.

Borhidi A. (1961): Klimadiagramme und klimazonale Karte Ungarns. - Annales Universitatis Scientiarum Budapestinensis, Sectio Biologica 4: 21-250.

BorHidi A. (1993): A magyar flóra szociális magatartás típusai, természetességi és relatív ökológiai értékszámai. - Janus Pannonius Tudományegyetem, Pécs, 95 pp.

BorHIDi A. (1995): Social behaviour types, the naturalness and relative ecological indicator values of the higher plants in the hungarian flora. - Acta Botanica Academiae Scientiarum Hungaricae 39: 97-181.

BoRHIDI A. \& KEVEY B. (1996): An annotated checklist of the hungarian plant communities II. - In: BoRHIDI A. (szerk.), Critical revision of the hungarian plant communities. Janus Pannonius University, Pécs, pp. 95-138.

Borhidi A., Kevey B. \& LendVAi G. (2012): Plant communities of Hungary. - Akadémiai Kiadó, Budapest, 544 pp. Braun-Blanquet J. (1964): Pflanzensoziologie (ed. 3.). - Springer Verlag, Wien-New York, 865 pp.

Horváth F., DobolyI Z. K., MoRschHAuSER T., LőKÖS L., KARAS L. \& SZERDAHElYI T. (1995): Flóra adatbázis 1.2. - MTA Ökológiai és Botanikai Kutatóintézete, Vácrátót, 267 pp.

JAKUCS P. (1967): Gedanken zur höheren Systematik der europäischen Laubwälder. - Contribuţii Botanice, Cluj 1967: 159-166.

JÁRAI-Komlódi M. (1966a): Palinológiai vizsgálatok a Magyar Alföldön a Würm glaciális és a holocén klíma- és vegetációtörténetére vonatkozóan. - Kandidátusi értekezés (Kézirat).

JÁRAI-KomLódI M. (1966b): Adatok az Alföld negyedkori klíma- és vegetációtörténetéhez I. - Botanikai Közlemények 53: 191-201.

JÁRAI-KomLódi M. (1968): The late glazial and holocene flora of the hungarian great plain. - Annales Universitatis Scientiarum Budapestinensis, Sectio Biologica 9-10: 199-225.

Kevey B. (2008): Magyarország erdőtársulásai [Forest associations of Hungary] - Tilia 14: 1-488. + CDadatbázis ( 230 táblázat +244 ábra).

KeveY B. \& HiRMAnN A. (2002): „NS” számítógépes cönológiai programcsomag. - In: HoRvÁTH A. (szerk.), Aktuális flóra- és vegetációkutatások a Kárpát-medencében V., Pécs, 2002. március 8-10. (Összefoglalók), Pécsi Tudományegyetem Növénytani Tanszék, Duna-Dráva Nemzeti Park Igazgatósága, Baranya Megyei Múzeumok Igazgatósága, Kosbor Természetvédelmi Egyesület, Pécs, pp. 74.

KIRÁLY G. (szerk.) (2009): Új magyar füvészkönyv. Magyarország hajtásos növényei. Határozókulcsok. Aggteleki Nemzeti Park Igazgatóság, Jósvafő, 616 pp.

Mucina L., Grabherr G. \& WAllNöFer S. (1993): Die Pflanzengesellschaften Österreichs III. Wälder und Gebüsche. - Gustav Fischer, Jena-Stuttgart-New York, 353 pp.

OBERDORFER E. (1953): Der europäische Auenwald. - Beiträge zur naturkundlichen Forschung in Südwestdeutschland 12: 23-70.

OBERDORFER E. (1992): Süddeutsche Pflanzengesellschaften IV. A. Textband. - Gustav Fischer Verlag, JenaStuttgart-New York, 282 pp. 
PAPP M., ANTAL M., DÁVID J. \& TöRÖK T. (1986): A Fényi erdő vegetációja. - Botanikai Közlemények 73 (1-2): 43-48.

PAWŁowski B., SокоŁowsкi M. \& WALlisch K. (1928): Die Pflanzenassoziationen des Tatra-Gebirges VII. Die Pflanzenassoziationen und die Flora des Morskie Oko-Tales. - Bulletin International de l'Academie Polonaise des Sciences et des Lettres, Classe des Sciences Mathématiques et Naturelles; Série B: Sciences Naturelles, Cracovie, Suppl. 1927: 205-272.

PodANi J. (2001): SYN-TAX 2000 Computer Programs for Data Analysis in Ecologi and Systematics. Scientia, Budapest, 53 pp.

Soó R. (1937): A Nyírség erdői és erdőtípusai. - Erdészeti Kísérletek 39: 337-380.

Soó R. (1938): A Nyírség vegetációja. - Magyar Tudományos Akadémia Matematikai és Természettudományi Értesítője 57: 888-910.

Soó R. (1943): A nyírségi erdők a növényszövetkezetek rendszerében. - Acta Geobotanica Hungarica 5: 315-352.

Soó R. (1953): A növénytakaró. - In: SzÉKESSY V. (szerk.), Bátorliget élővilága. Akadémiai Kiadó, Budapest, pp. 45-57.

Soó R. (1960): Magyarország új florisztikai-növényföldrajzi felosztása. - Magyar Tudományos Akadémia Biológiai Csoportjának Közleményei 4: 43-70.

Soó R. (1963): Systematische Übersicht der pannonischen Pflanzengesellschaften VI. Die Gebirgswälder II. - Acta Botanica Academiae Scientiarum Hungaricae 9: 123-150.

Soó R. (1964, 1966, 1968, 1970, 1973, 1980): A magyar flóra és vegetáció rendszertani-növényföldrajzi kézikönyve I-VI. - Akadémiai kiadó, Budapest.

VLIEGER J. (1937): Aperçu sur les unités phytosociologiques supérieures des Pays-Bas. - Nederlandsh Kruidkundig Archief 47: 335.

ZóLYoмi B. (1936): Tízezer év története virágporszemekben. - Természettudományi Közlöny 68: 504-516.

ZóLYoмi B. (1952): Magyarország növénytakarójának fejlődéstörténete az utolsó jégkorszaktól. Magyar Tudományos Akadémia Biológiai Osztályának Közleményei 1: 491-530.

Beérkezett: 2016. 11. 25. • Elfogadva: 2017.01. 19. 
KEVEY et al. (2017) - Kitaibelia 22 (1): 179-220.

1. táblázat. Fraxino pannonicae-Ulmetum (Nyugati-Nyírség)

Table 1. Fraxino pannonicae-Ulmetum (W Nyírség)

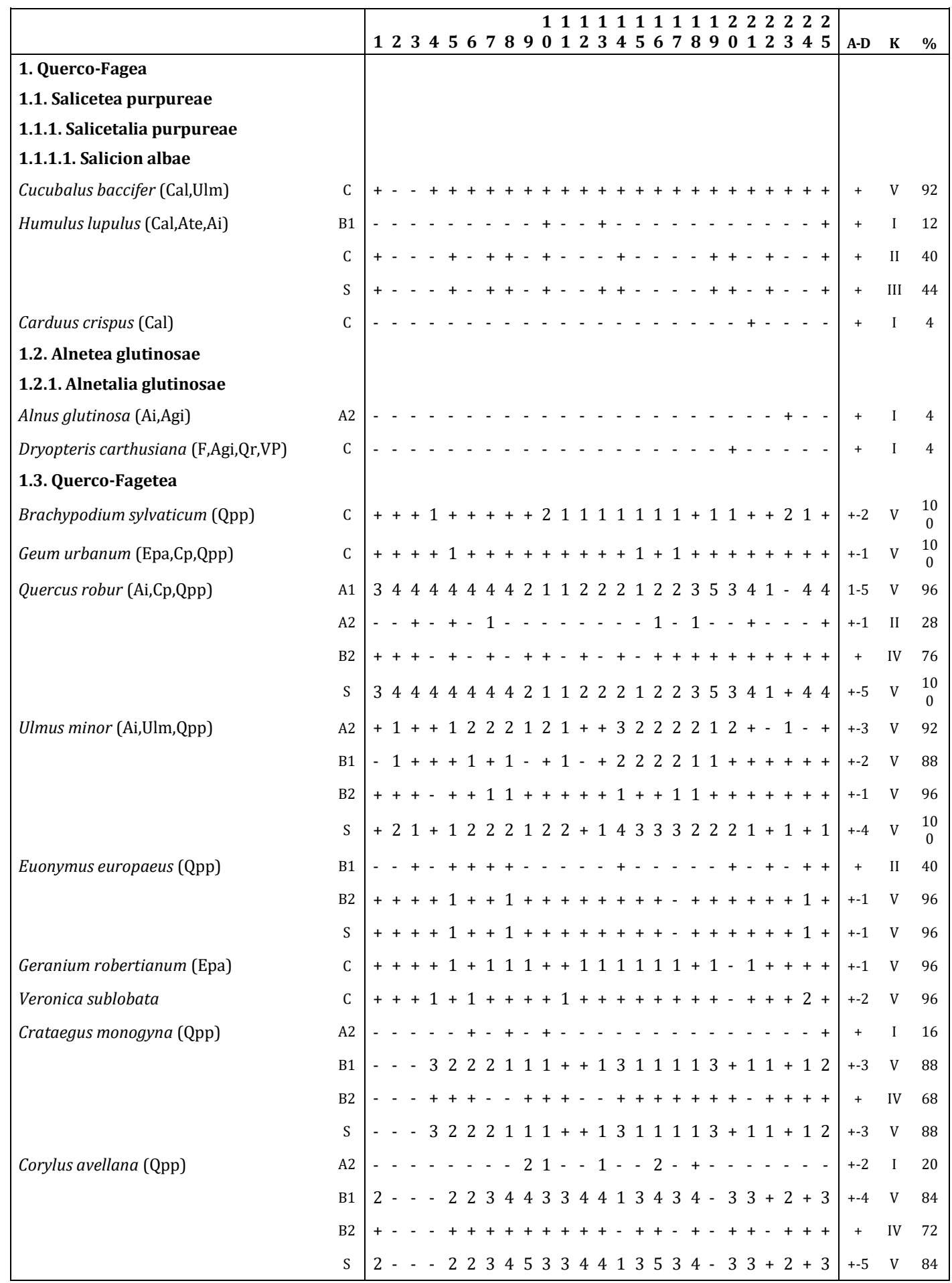




\begin{tabular}{|c|c|c|c|c|c|c|c|c|c|c|c|c|c|c|c|c|c|c|c|c|c|c|c|c|c|c|c|}
\hline & & & 3 & & & & & & & & & & & & & & & & & & & & & 5 & A-D & $\mathbf{K}$ & $\%$ \\
\hline \multirow[t]{3}{*}{ Ligustrum vulgare (Cp,Qpp) } & B1 & - & - & - & + & + & 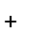 & + & + & ++ & +- & - & + & -+ & +1 & & & - 1 & & - & - & + & + & 1 & +-2 & IV & 68 \\
\hline & B2 & - & - & - & 1 & + & 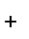 & 1 & + & + & + & + & & & +2 & & & 2 & 2 & + & + & & 1 & + & +-2 & $\mathrm{~V}$ & 84 \\
\hline & $\mathrm{S}$ & - & - & - & 1 & + & + & 1 & + & ++ & ++ & + & ++ & & +2 & & & 2 & 3 & + & + & & 1 & 1 & +-3 & $\mathrm{~V}$ & 84 \\
\hline Galeopsis pubescens (Qpp,Epa) & $\mathrm{C}$ & ++ & + & - & + & + & + & + & + & ++ & +- & - & ++ & ++ & ++ & & & + & - & + & - & - & + & + & + & IV & 80 \\
\hline Polygonatum latifolium (Qpp) & $\mathrm{C}$ & 11 & 2 & 1 & 1 & 2 & 2 & + & + & - & -+ & + & 13 & 34 & 42 & 3 & 3 & - & 1 & 1 & - & + & - & - & +-4 & IV & 76 \\
\hline \multirow[t]{4}{*}{ Cornus sanguinea (Qpp) } & A2 & -- & - & - & - & - & - & - & - & - & - & - & - & - & - & - & - & - & - & - & - & + & - & - & + & I & 4 \\
\hline & B1 & $-\quad-$ & - & - & - & - & + & - & + & - & + & - & +1 & 1 - & -1 & & & + & + & - & 2 & 2 & - & + & +-2 & III & 52 \\
\hline & B2 & $-\quad-$ & - & - & - & + & 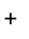 & - & + & + & + & + & + & & ++ & & & + & + & + & + & + & - & + & + & IV & 72 \\
\hline & $\mathrm{S}$ & $-\quad-$ & - & - & - & + & 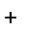 & - & + & + & + & + & +1 & $1+$ & +1 & & & + & + & + & 2 & 2 & - & + & +-2 & IV & 72 \\
\hline Lapsana communis (Qpp,GA,Epa) & $\mathrm{C}$ & -- & + & + & + & - & + & - & + & +- & -+ & + & ++ & ++ & ++ & & & + & - & + & + & + & - & + & + & IV & 72 \\
\hline Dactylis polygama (Qpp,Cp) & $\mathrm{C}$ & -+ & + & 1 & + & + & + & + & - & - - & - - & - & -+ & +1 & $1+$ & & . & + & + & + & + & + & - & - & +-1 & IV & 68 \\
\hline Convallaria majalis (Qpp) & $\mathrm{C}$ & -- & - & - & - & - & - & - & 2 & 2 & 11 & 1 & 1 & ++ & +1 & 3 & 3 & 1 & 2 & - & + & + & + & + & +-3 & IV & 64 \\
\hline Carex divulsa ssp. divulsa & $\mathrm{C}$ & -+ & + & + & + & + & - & - & + & +- & - & + & - & -- & -+ & & + & + & - & + & - & - & + & + & + & III & 60 \\
\hline Fallopia dumetorum (Qpp,GA) & $\mathrm{C}$ & ++ & + & + & + & + & + & - & - & - & - & - & - & +- & -+ & 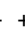 & + & + & - & + & - & - & + & + & + & III & 60 \\
\hline Viola suavis s.l. (Qpp) & $\mathrm{C}$ & ++ & + & + & 2 & 2 & 2 & 2 & - & - & - & - & -+ & ++ & +- & - & - & - & - & + & + & - & + & + & +-2 & III & 56 \\
\hline Ranunculus ficaria & $\mathrm{C}$ & 22 & 4 & 2 & 4 & 4 & 4 & 4 & - & - & - & - & - & - & - & + & 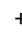 & + & - & - & - & - & 3 & 3 & +-4 & III & 52 \\
\hline \multirow[t]{5}{*}{ Acer campestre (Qpp) } & $\mathrm{A} 1$ & - & - & - & 1 & + & - & - & - & - & - & - & - & - & - & 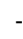 & 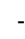 & - & - & - & - & - & - & - & +-1 & I & 8 \\
\hline & A2 & 43 & 4 & 4 & 2 & 2 & - & - & - & - & - & - & - & - & - & - & - & - & - & - & + & - & - & - & +-4 & II & 28 \\
\hline & B1 & 23 & 2 & 1 & 1 & 2 & + & 1 & - & - & - & 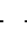 & - & - & - & - & - & - & - & - & + & & - & + & +-3 & III & 44 \\
\hline & B2 & +1 & + & + & + & + & + & + & - & - & - & - & - & - & - & - & - & - & - & - & + & & - & + & +-1 & III & 44 \\
\hline & $\mathrm{S}$ & 55 & 5 & 4 & 2 & 3 & + & 1 & - & - & - & 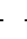 & - & - & - & - & - & - & - & - & 1 & + & - & + & +-5 & III & 44 \\
\hline Scrophularia nodosa (GA,Epa) & $\mathrm{C}$ & $-\quad-$ & - & - & + & - & - & - & + & + & + & + & - & - & - - & + & 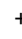 & 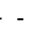 & + & + & - & - & + & - & + & II & 40 \\
\hline Mycelis muralis & $\mathrm{C}$ & -- & - & - & - & - & - & - & + & ++ & ++ & + & + & - & -+ & t & & . & - & - & - & - & - & + & + & II & 36 \\
\hline Primula veris (Qpp,Ara) & $\mathrm{C}$ & - - & - & - & - & - & - & - & + & + & + & + & + & - & ++ & T & & 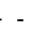 & - & - & - & - & - & - & + & II & 36 \\
\hline \multirow[t]{3}{*}{ Rhamnus catharticus (Qpp,Pru) } & B1 & -- & - & + & - & - & - & - & - & - & - & - & - & - & ++ & + & & - & - & - & - & - & - & - & + & I & 20 \\
\hline & B2 & -- & - & - & - & - & + & - & - & - & - & - & - & - & + & - & - & - & + & + & - & - & - & - & + & I & 20 \\
\hline & $\mathrm{S}$ & -- & - & + & - & - & + & - & - & - & - & - & - & 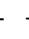 & + & + & & - & + & + & - & - & - & - & + & II & 32 \\
\hline Bromus ramosus agg. (Qpp) & $\mathrm{C}$ & -+ & + & 1 & - & - & + & + & - & - & - & - & - & - & - - & 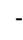 & 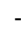 & - & - & - & - & - & + & + & +-1 & II & 28 \\
\hline Poa nemoralis (Qpp) & $\mathrm{C}$ & +- & - & - & + & + & + & + & - & - & - & - & - & - & - - & - & - & - & - & - & - & - & + & - & + & II & 24 \\
\hline Heracleum sphondylium (Qpp,MoA) & $\mathrm{C}$ & - - & - & - & - & - & - & - & - & - & - & - & - & - & - - & + & 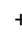 & - & - & - & + & + & - & - & + & I & 16 \\
\hline Viola mirabilis $(\mathrm{F}, \mathrm{Qpp})$ & $\mathrm{C}$ & -- & - & - & - & - & - & - & - & - & - & - & - & - & - - & - & - & - & - & + & - & 2 & + & + & +-2 & I & 16 \\
\hline Campanula trachelium (Epa,Cp) & $\mathrm{C}$ & -- & - & - & - & - & - & - & - & - & - & - & - & 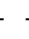 & - & - & 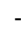 & - & - & + & + & & - & - & + & I & 12 \\
\hline Ranunculus auricomus agg. (MoA) & $\mathrm{C}$ & -- & - & - & - & - & - & - & - & - & 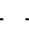 & - & - & + & + & - & - & - & + & - & - & - & - & - & + & I & 12 \\
\hline Loranthus europaeus & A1 & -- & - & - & - & - & + & - & - & - & - & - & - & - & - & - & - & - & + & - & - & - & - & - & + & I & 8 \\
\hline \multirow[t]{3}{*}{ Populus tremula (Qr,Qc,Ber) } & B1 & -- & - & - & - & - & - & - & - & - & - & - & - & - & - & - & - & $T$ & + & - & - & - & - & - & + & I & 8 \\
\hline & B2 & -- & - & - & - & - & - & - & - & - & - & - & - & - & - & - & - & 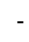 & + & - & - & - & - & - & + & I & 4 \\
\hline & $\mathrm{S}$ & -- & - & - & - & - & - & - & - & - & - & - & - & - & - & 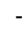 & - & + & + & - & - & - & - & - & + & I & 8 \\
\hline Vicia sepium (Ara,Qpp) & $\mathrm{C}$ & -- & - & - & - & - & - & - & - & - & - & - & - & 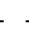 & - & 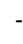 & - & + & - & - & - & - & + & - & + & I & 8 \\
\hline Viola odorata & $\mathrm{C}$ & ++ & - & - & - & - & - & 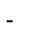 & - & - & - & - & - & - & 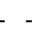 & 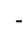 & - & 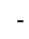 & - & - & - & - & - & - & + & I & 8 \\
\hline Carex spicata (Qpp,Epa) & $\mathrm{C}$ & - - & - & - & - & - & - & - & - & - & - & - & - & - & - & 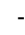 & - & - & + & - & - & - & - & - & + & I & 4 \\
\hline
\end{tabular}


KEVEY et al. (2017) - Kitaibelia 22 (1): 179-220.

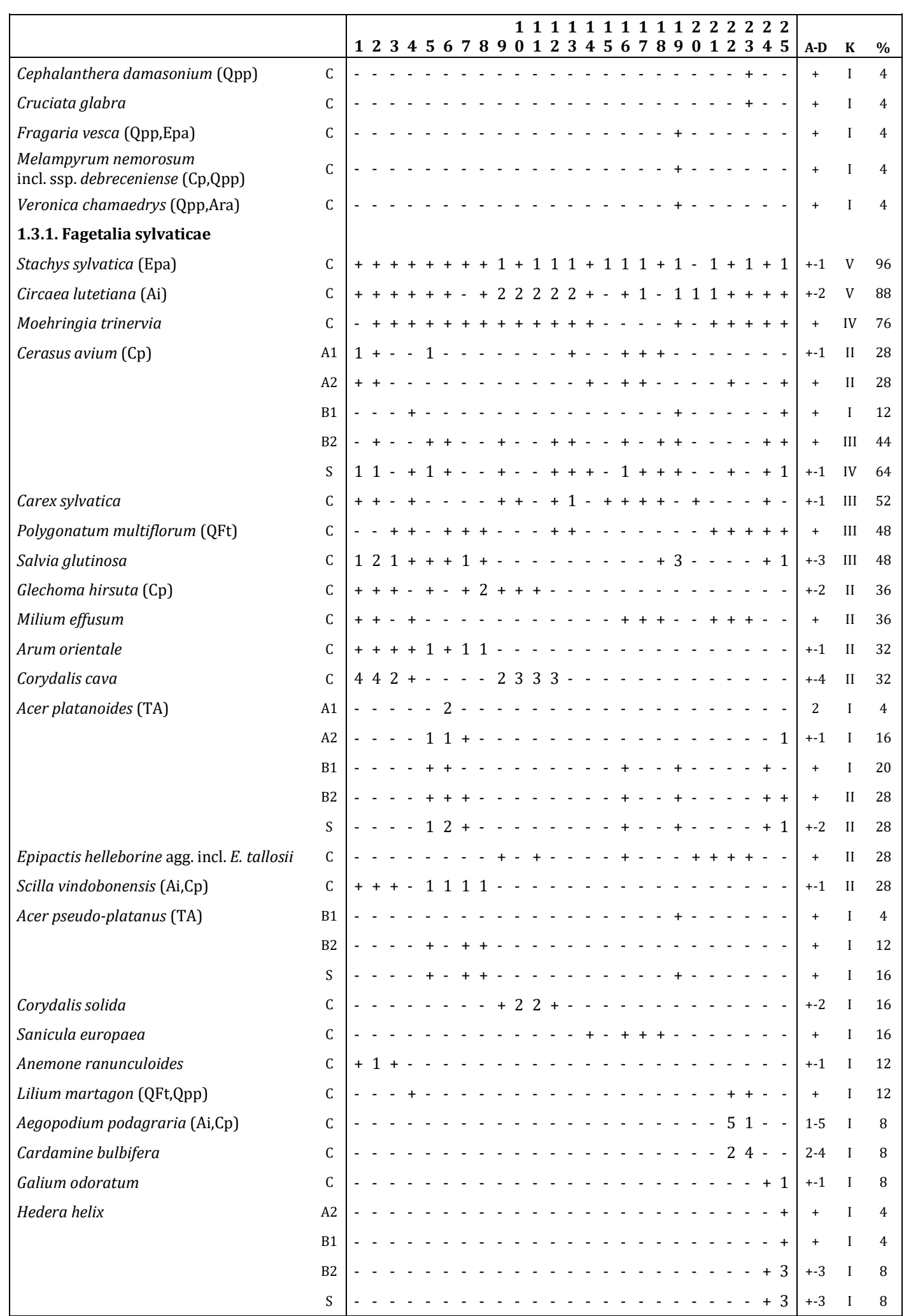


KEVEY et al. (2017) - Kitaibelia 22 (1): 179-220.

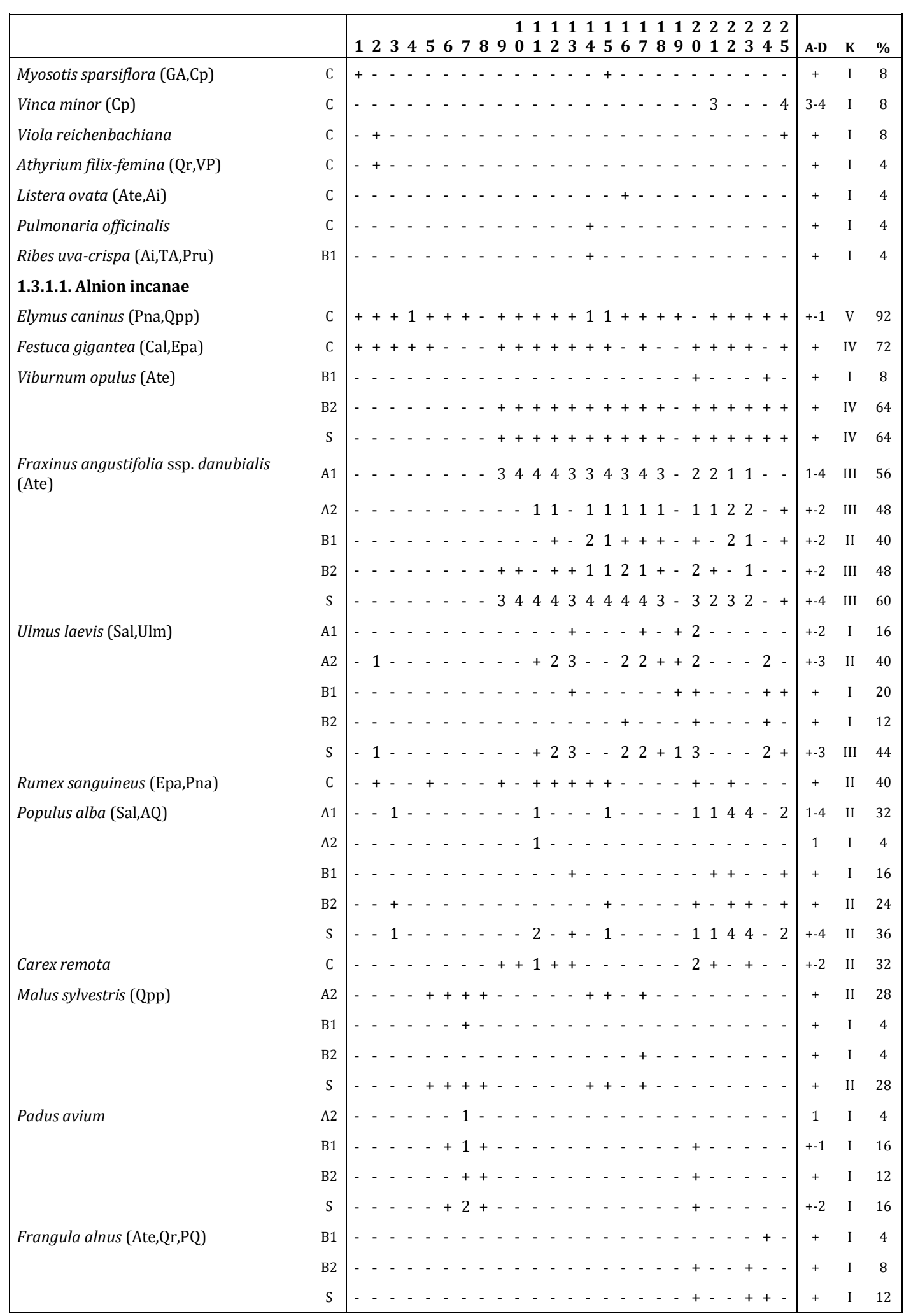


KEVEY et al. (2017) - Kitaibelia 22 (1): 179-220.

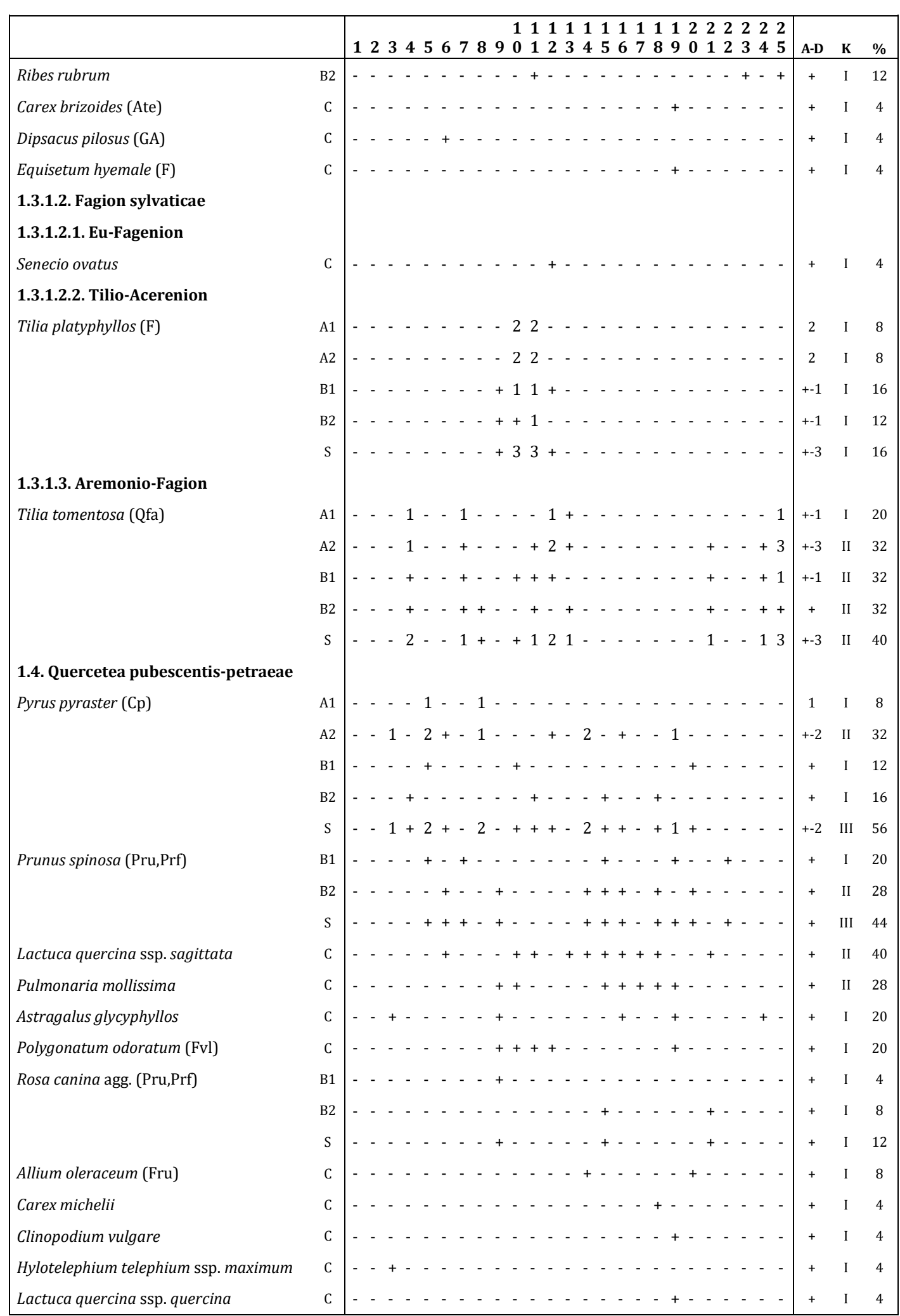


KEVEY et al. (2017) - Kitaibelia 22 (1): 179-220.

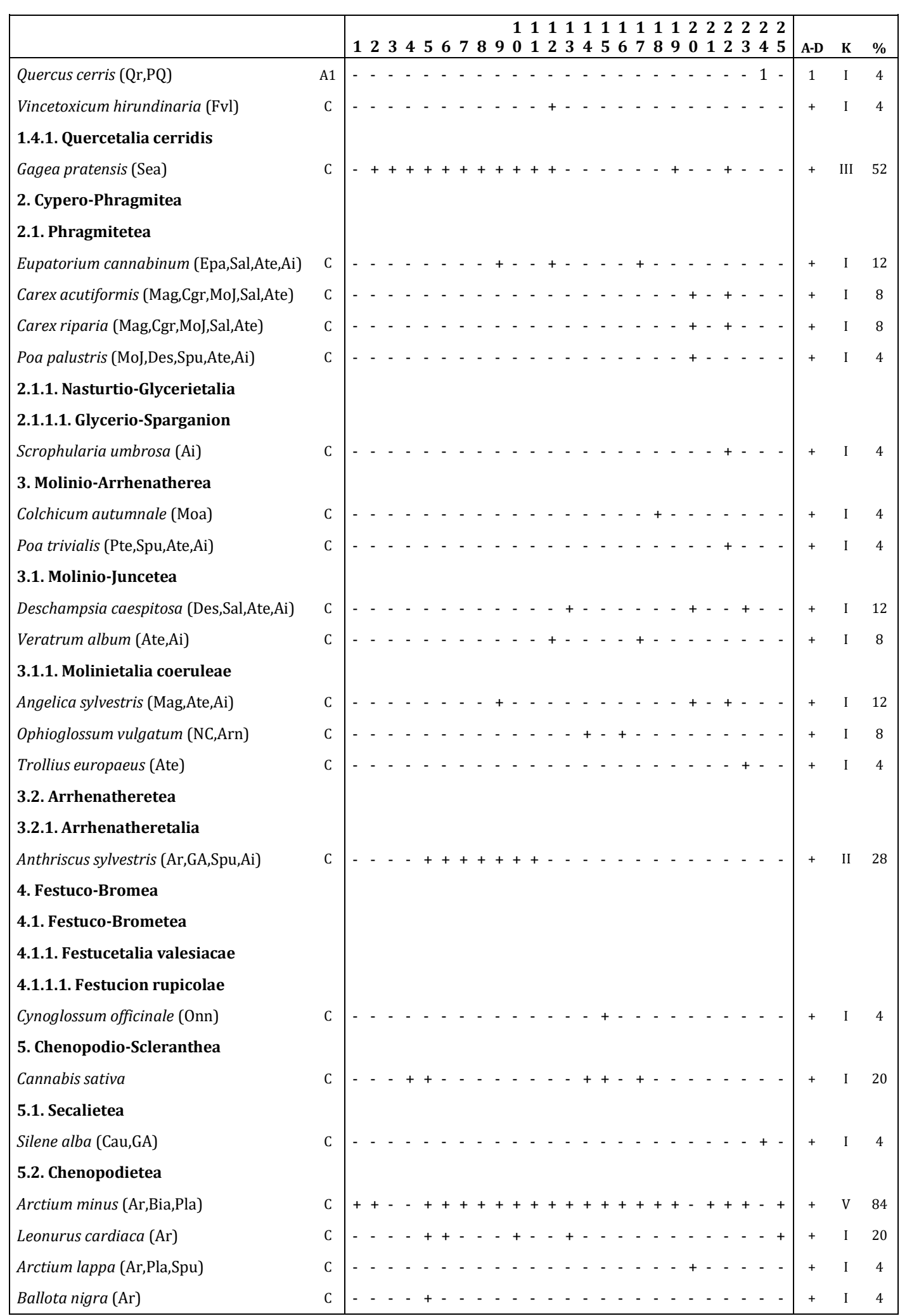


KEVEY et al. (2017) - Kitaibelia 22 (1): 179-220.

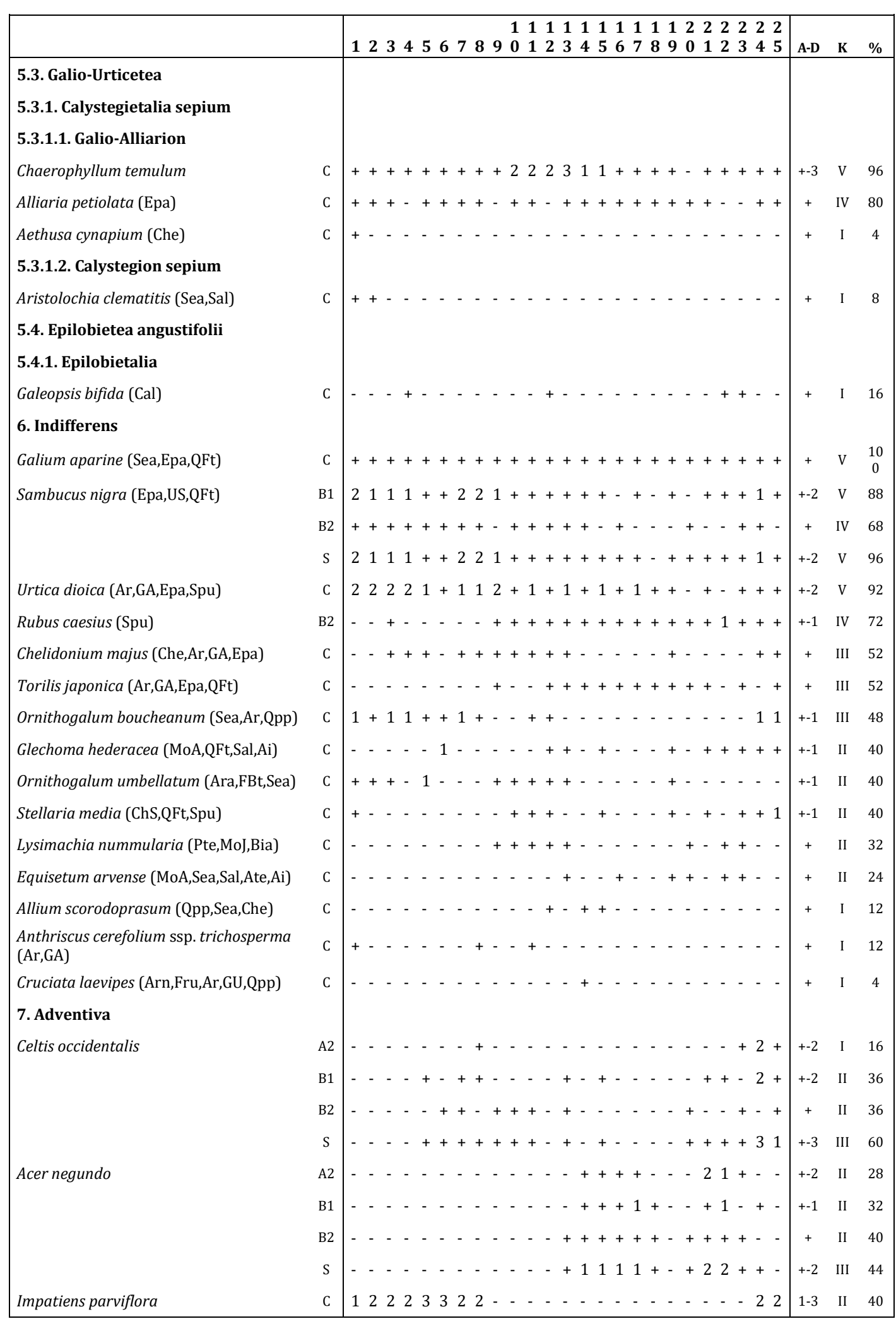


KEVEY et al. (2017) - Kitaibelia 22 (1): 179-220.

\begin{tabular}{|c|c|c|c|c|c|c|c|c|c|c|c|c|c|c|c|c|c|c|c|c|c|c|c|c|c|c|c|}
\hline & & 12 & & 4 & & & & & & & & & & & & & & & & & & & & $\begin{array}{l}2 \\
5\end{array}$ & A-D & $\mathbf{K}$ & $\%$ \\
\hline \multirow{5}{*}{ Robinia pseudo-acacia } & A1 & -- & + & + & 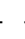 & 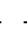 & 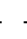 & 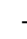 & - & - & + & + & - & - & - & - & - & - & - & - & - & - & - & - & + & I & 16 \\
\hline & A2 & $-\quad-$ & - & - & - & 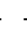 & 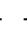 & . & - & - & - & - & - & - & - & - & - & + & - & + & - & - & - & - & + & I & 8 \\
\hline & B1 & +- & - & - & + & 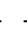 & - & - & - & - & - & - & - & - & - & - & - & - & - & - & - & - & - & - & + & I & 8 \\
\hline & B2 & -- & + & - & + & 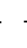 & + & - & - & - & - & + & - & - & + & - & - & + & - & - & - & - & - & - & + & II & 24 \\
\hline & S & +- & + & + & + & & + & - & - & - & + & + & - & - & + & - & - & + & - & + & - & - & - & - & + & II & 40 \\
\hline \multirow[t]{4}{*}{ Padus serotina } & A2 & -- & - & - & - & 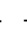 & + & 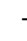 & - & - & - & - & - & - & - & - & - & - & - & - & - & - & - & - & + & I & 4 \\
\hline & B1 & -2 & + & - & - & 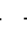 & + & . & - & - & - & - & - & - & - & - & - & - & - & - & - & - & + & - & +-2 & I & 16 \\
\hline & B2 & -- & + & + & - &. & + & & - & - & - & - & - & - & - & - & - & - & - & + & - & - & + & + & + & II & 24 \\
\hline & S & -2 & + & + & - & 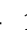 & 1 & & - & - & - & - & - & - & - & - & - & - & - & + & - & - & + & + & +-2 & II & 28 \\
\hline \multirow[t]{3}{*}{ Juglans regia } & B1 & -- & - & - & - & + & - & - & - & - & - & - & - & - & - & - & - & - & - & - & - & - & - & - & + & I & 4 \\
\hline & B2 & -- & - & - & + & . & + & . & - & - & - & - & - & - & - & - & - & - & - & + & - & - & - & - & + & I & 12 \\
\hline & S & -- & - & - & + & + & + & 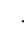 & - & - & - & - & - & - & - & - & - & - & - & + & - & - & - & - & + & I & 16 \\
\hline \multirow[t]{4}{*}{ Fraxinus pennsylvanica } & $\mathrm{A} 1$ & -- & - & - & - & -1 & 1 & . & - & - & - & - & - & - & - & - & - & - & - & - & - & - & - & - & 1 & I & 4 \\
\hline & A2 & -- & - & - & - & + & & 1 & - & - & - & - & - & - & - & - & - & - & - & - & - & - & - & - & +-1 & I & 8 \\
\hline & B2 & -- & - & - & 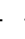 & + & & & - & - & - & - & - & - & - & - & - & - & - & - & - & - & - & - & + & I & 4 \\
\hline & S & -- & - & - & - & + & 1 & 1 - & - & - & - & - & - & - & - & - & - & - & - & - & - & - & - & - & +-1 & I & 12 \\
\hline Juglans nigra & B2 & -+ & - & - & - & 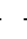 & 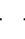 & - & - & - & - & - & - & - & - & - & - & - & - & - & - & - & + & + & + & I & 12 \\
\hline Gleditsia triacanthos & B2 & -- & - & - & + & - & - & + & - & - & - & - & - & - & - & - & - & - & - & - & - & - & - & - & + & I & 8 \\
\hline Parthenocissus inserta & B2 & -- & - & - & 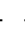 & 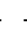 & 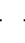 & & - & - & - & + & - & - & - & - & - & - & - & - & - & - & - & - & +-1 & I & 8 \\
\hline Phytolacca americana & $\mathrm{C}$ & -- & - & - & 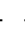 & 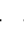 & & & - & - & - & - & - & - & - & - & - & - & - & - & - & - & + & + & + & I & 8 \\
\hline Quercus rubra & B2 & -- & + & - & + & 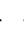 & & 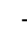 & - & - & - & - & - & - & - & - & - & - & - & - & - & - & - & - & + & I & 8 \\
\hline Ailanthus altissima & B2 & -- & - & - & + & 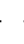 & 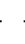 & - & - & - & - & - & - & - & - & - & - & - & - & - & - & - & - & - & + & I & 4 \\
\hline Deutzia scabra & B1 & -- & - & - & 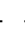 & 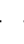 & 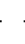 & & - & - & - & - & - & - & - & - & - & - & - & - & - & - & - & - & + & I & 4 \\
\hline Stenactis annua & $\mathrm{C}$ & -- & - - & - & - & 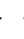 & & & - & - & - & - & - & - & - & - & - & - & - & - & - & - & - & - & + & I & 4 \\
\hline \multirow[t]{3}{*}{ Vitis riparia } & A2 & -- & - & - & 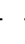 & 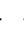 & 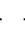 & 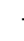 & - & - & - & - & - & - & - & - & - & - & + & - & - & - & - & - & + & I & 4 \\
\hline & B2 & -- & - & - & - & 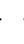 & 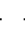 & 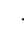 & - & - & - & - & - & - & - & - & - & - & + & - & - & - & - & - & + & I & 4 \\
\hline & S & -- & - & & & & - & & - & - & - & - & - & - & - & - & - & - & + & - & - & - & - & - & + & I & 4 \\
\hline
\end{tabular}


2. táblázat. Felvételi adatok az 1. táblázathoz (Nyugati-Nyírség) / Table 2. Data of the relevés in Table 1. (W Nyírség)

\begin{tabular}{|c|c|c|c|c|c|c|c|c|c|c|c|c|c|c|c|c|c|c|c|c|c|c|c|c|c|}
\hline & 1 & 2 & 3 & 4 & 5 & 6 & 7 & 8 & 9 & 10 & 11 & 12 & 13 & 14 & 15 & 16 & 17 & 18 & 19 & 20 & 21 & 22 & 23 & 24 & 25 \\
\hline Minta felvételi sorszáma & 8816 & 8817 & 8818 & 8824 & 8819 & 8820 & 8821 & 8822 & 8855 & 8856 & 8857 & 8858 & 8859 & 8850 & 8851 & 8852 & 8853 & 8854 & 8839 & 12725 & 8860 & 88618 & 8862 & 5950 & 5951 \\
\hline Felvételi évszám 1. & 2003 & 2003 & 2003 & 2003 & 2003 & 2003 & 2003 & 2003 & 2003 & 2003 & 2003 & 2003 & 2003 & 2003 & 2003 & 2003 & 2003 & 2003 & 2003 & 2005 & 2003 & 20032 & 2003 & 2004 & 2004 \\
\hline Felvételi időpont 1. & 04.12 & 04.12 & 04.12 & 04.12 & 04.12 & 04.12 & 04.12 & $04.12 c$ & 04.10 & 04.10 & 04.10 & 04.10 & 04.10 & $04.10 \mathrm{c}$ & 04.10 & 04.10 & 04.10 & 04.10 & 04.11 & 04.29 & 04.12 & 04.120 & $04.12 \mathrm{c}$ & 04.29 & 04.29 \\
\hline Felvételi évszám 2. & 2003 & 2003 & 2003 & 2003 & 2003 & 2003 & 2003 & 2003 & 2003 & 2003 & 2003 & 2003 & 2003 & 2003 & 2003 & 2003 & 2003 & 2003 & 2003 & 2005 & 2003 & 20032 & 20032 & 2004 & 2004 \\
\hline Felvételi időpont 2. & 07.20 & 07.20 & 07.20 & 07.20 & 07.20 & 07.20 & 07.20 & $07.20 \mathrm{c}$ & 07.18 & 07.18 & 07.18 & 07.18 & 07.18 & $07.18 \mathrm{c}$ & 07.18 & 07.18 & 07.18 & 07.18 & 07.19 & 08.20 & 07.17 & 07.120 & $07.17 \mathrm{c}$ & 06.28 & 06.28 \\
\hline Tengerszint feletti magasság (m) & 130 & 130 & 130 & 128 & 135 & 135 & 135 & 135 & 122 & 122 & 122 & 122 & 121 & 125 & 125 & 125 & 125 & 125 & 150 & 134 & 138 & 138 & 138 & 137 & 137 \\
\hline Kitettség & - & - & - & - & - & - & - & - & - & - & - & - & - & - & - & - & - & - & - & - & - & - & - & - & - \\
\hline Felső lombkoronaszint borítása (\%) & 50 & 65 & 60 & 60 & 80 & 75 & 65 & 75 & 60 & 65 & 75 & 75 & 60 & 50 & 70 & 50 & 70 & 65 & 80 & 70 & 65 & 65 & 70 & 70 & 80 \\
\hline Alsó lombkoronaszint borítása (\%) & 60 & 40 & 60 & 60 & 30 & 40 & 20 & 30 & 15 & 30 & 30 & 30 & 40 & 40 & 20 & 60 & 40 & 20 & 5 & 30 & 20 & 25 & 25 & 35 & 40 \\
\hline Cserjeszint borítása (\%) & 25 & 60 & 25 & 50 & 35 & 50 & 75 & 75 & 75 & 50 & 50 & 60 & 65 & 70 & 50 & 70 & 70 & 75 & 40 & 60 & 50 & 50 & 40 & 30 & 60 \\
\hline Újulat borítása (\%) & 1 & 3 & 1 & 1 & 5 & 1 & 3 & 10 & 3 & 3 & 3 & 1 & 1 & 10 & 2 & 30 & 5 & 2 & 25 & 40 & 1 & 5 & 5 & 5 & 40 \\
\hline Gyepszint borítása (\%) & 90 & 90 & 90 & 60 & 85 & 80 & 75 & 80 & 70 & 85 & 80 & 80 & 70 & 70 & 70 & 40 & 90 & 70 & 70 & 40 & 50 & 95 & 90 & 70 & 95 \\
\hline Felső lombkoronaszint magassága (m) & 30 & 30 & 30 & 25 & 25 & 30 & 30 & 30 & 28 & 30 & 30 & 30 & 25 & 25 & 28 & 28 & 30 & 30 & 28 & 25 & 30 & 30 & 30 & 30 & 30 \\
\hline Alsó lombkoronaszint magassága (m) & 20 & 16 & 18 & 18 & 20 & 18 & 20 & 20 & 12 & 15 & 20 & 18 & 12 & 16 & 15 & 13 & 20 & 17 & 13 & 16 & 15 & 16 & 16 & 18 & 20 \\
\hline Cserjeszint magassága $(\mathrm{cm})$ & 2,5 & 4 & 3 & 2,5 & 2 & 3,5 & 3,5 & 3,5 & 4,5 & 4 & 4,5 & 4 & 4 & 2,5 & 3 & 2,5 & 3,5 & 5 & 2,5 & 3,5 & 4 & 4 & 3,5 & 3 & 3,5 \\
\hline Átlagos törzsátmérő $(\mathrm{cm})$ & 70 & 75 & 75 & 60 & 45 & 70 & 70 & 70 & 60 & 65 & 70 & 65 & 60 & 60 & 70 & 75 & 70 & 75 & 55 & 50 & 70 & 65 & 75 & 50 & 60 \\
\hline Felvételi terület nagysága $\left(\mathrm{m}^{2}\right)$ & 1600 & 1600 & 1600 & 1600 & 1600 & 1600 & 1600 & 1600 & 1600 & 1600 & 1600 & 1600 & 1600 & 1600 & 1600 & 1600 & 1600 & 1600 & 1600 & 1600 & 1600 & 16001 & 16001 & 1600 & 1600 \\
\hline
\end{tabular}


3. táblázat. Fraxino pannonicae-Ulmetum (Keleti-Nyírség) / Table 3. Fraxino pannonicae-Ulmetum (E Nyírség)

\begin{tabular}{|c|c|c|c|}
\hline & & 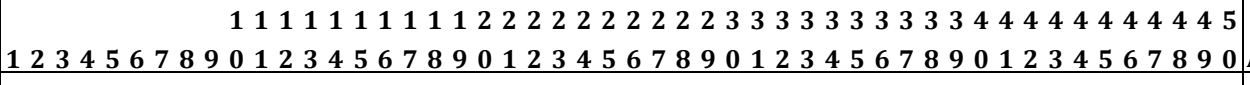 & A-D K $\quad \%$ \\
\hline $\begin{array}{l}\text { 1. Querco-Fagea } \\
\text { 1.1. Salicetea purpureae } \\
\text { 1.1.1. Salicetalia purpureae }\end{array}$ & & & \\
\hline $\begin{array}{l}\text { Populus nigra } \\
\text { 1.1.1.1. Salicion albae }\end{array}$ & A1 & 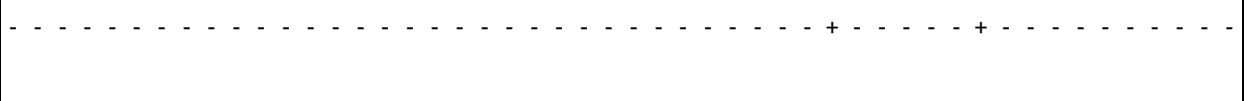 & $+\mathrm{I} 4$ \\
\hline Cucubalus baccifer (Cal,Ulm) & C & 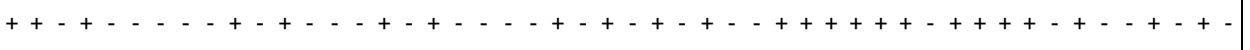 & + III 48 \\
\hline Humulus lupulus (Cal,Ate,Ai) & \begin{tabular}{c|}
$\mathrm{B} 1$ \\
$\mathrm{C}$ \\
$\mathrm{S}$
\end{tabular} & 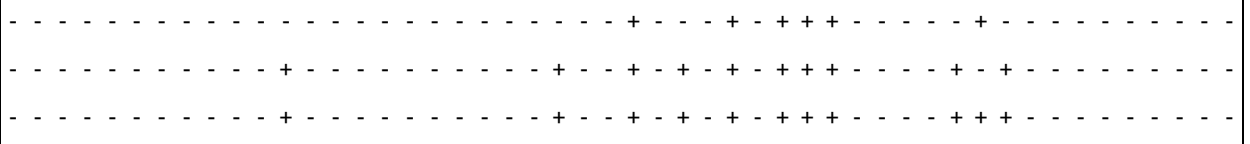 & 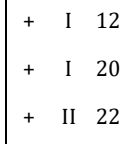 \\
\hline Salix fragilis (Ai,Cal) & \begin{tabular}{r|r}
$\mathrm{A} 1$ & $\mathrm{~A} 2$ \\
$\mathrm{~S}$ &
\end{tabular} & 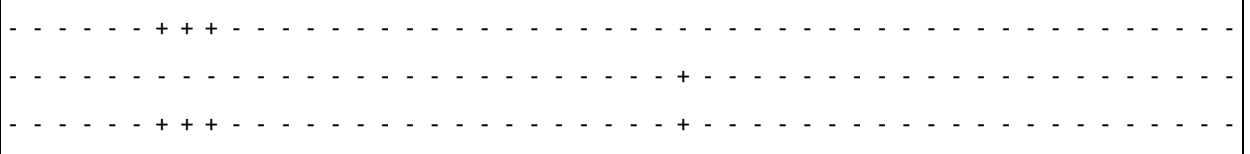 & 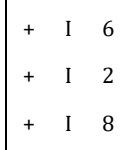 \\
\hline $\begin{array}{l}\text { Leucojum aestivum (Des) } \\
\text { 1.2. Alnetea glutinosae } \\
\text { 1.2.1. Alnetalia glutinosae }\end{array}$ & c & 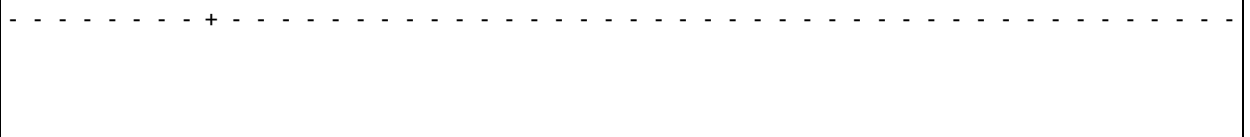 & $+\quad I \quad 2$ \\
\hline $\begin{array}{l}\text { Dryopteris carthusiana (F,Agi,Qr,VP) } \\
\text { 1.3. Querco-Fagetea }\end{array}$ & $\mathrm{C}$ & $+\ldots \ldots+\ldots+\ldots+\ldots+\ldots+\ldots+\ldots+\ldots+\ldots+\ldots+\ldots+\ldots+\ldots+\ldots+\ldots+\ldots$ & $+\quad \mathrm{I} 8$ \\
\hline Quercus robur (Ai,Cp,Qpp) & \begin{tabular}{c|} 
A1 \\
A2 \\
B1 \\
B2 \\
S
\end{tabular} & 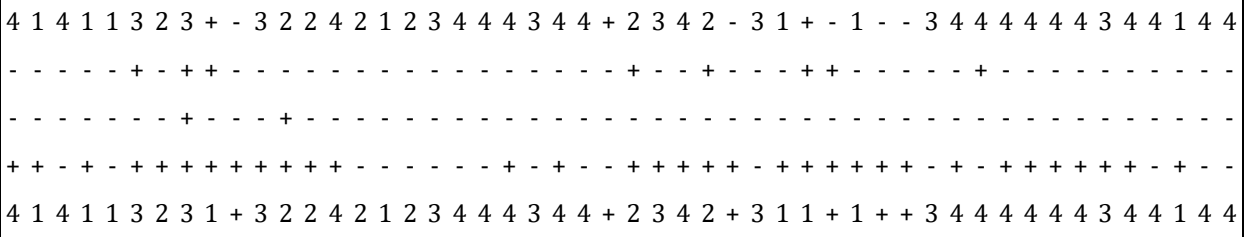 & $\begin{array}{lll}+-4 & \text { V } & 90 \\
+ & \text { I } & 16 \\
+ & \text { I } & 4 \\
+ & \text { IV } & 66 \\
+-4 & \text { V } & 100\end{array}$ \\
\hline Ulmus minor (Ai,Ulm,Qpp) & \begin{tabular}{l|}
$\mathrm{A} 2$ \\
$\mathrm{~B} 1$ \\
$\mathrm{~B} 2$
\end{tabular} & $\begin{array}{l}-+++++++++-12-++++++-2+-1+1-+1--1-21+-++-+--11-1 \\
++1++++++++++1+++++2++1-12+++++++1-+1-++1+++++121+ \\
++++++-++-++++++++++++++++++++++++++++++++++++++++ \\
++11111+11+1+12+1+1+21+2+1211+11++2+22+++1+1+++2211\end{array}$ & $\mid \begin{array}{lll}+-2 & \text { III } & 60 \\
+-2 & \mathrm{~V} & 94 \\
+ & \mathrm{V} & 96 \\
+-2 & \mathrm{~V} & 100\end{array}$ \\
\hline
\end{tabular}




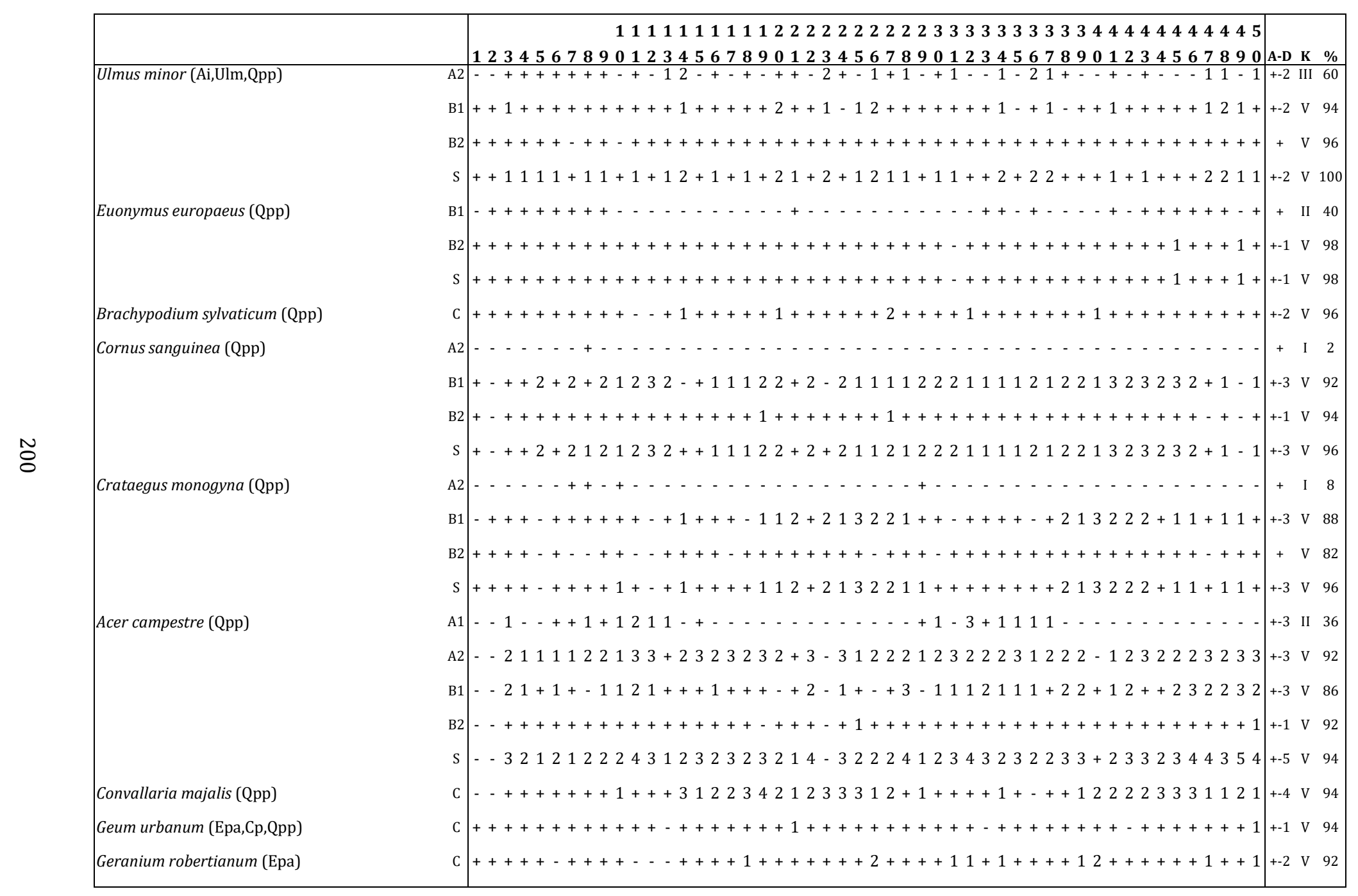




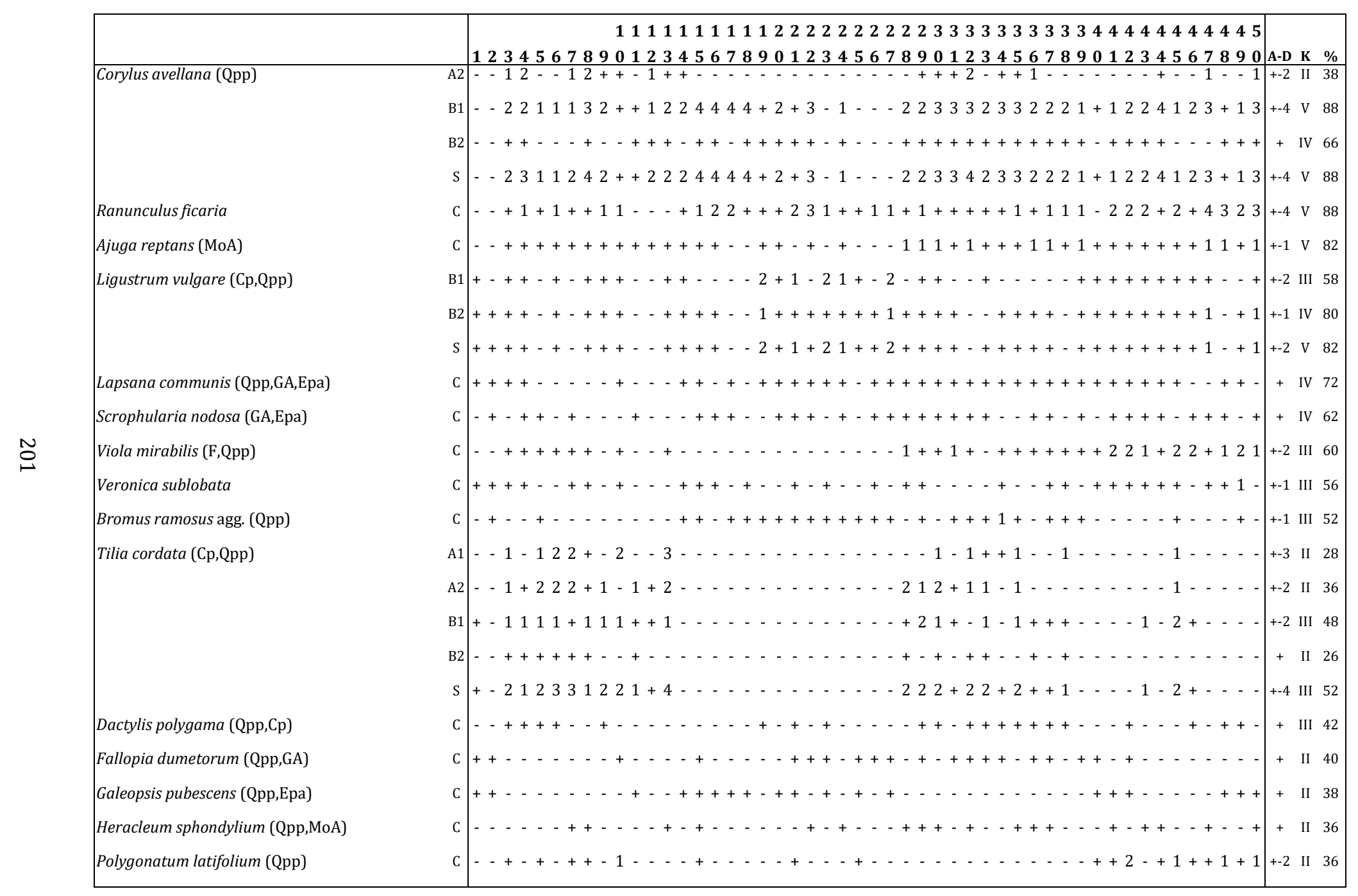




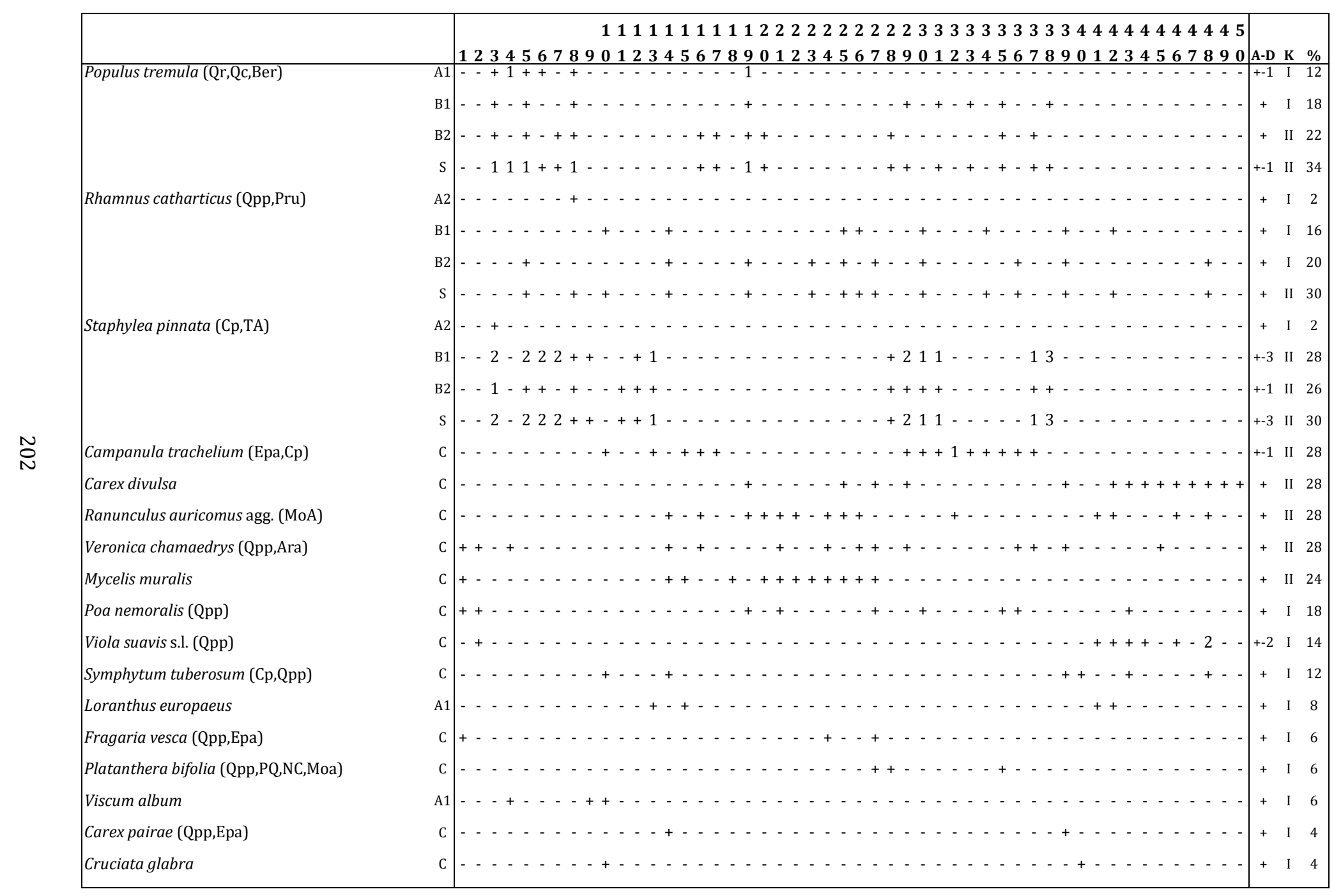




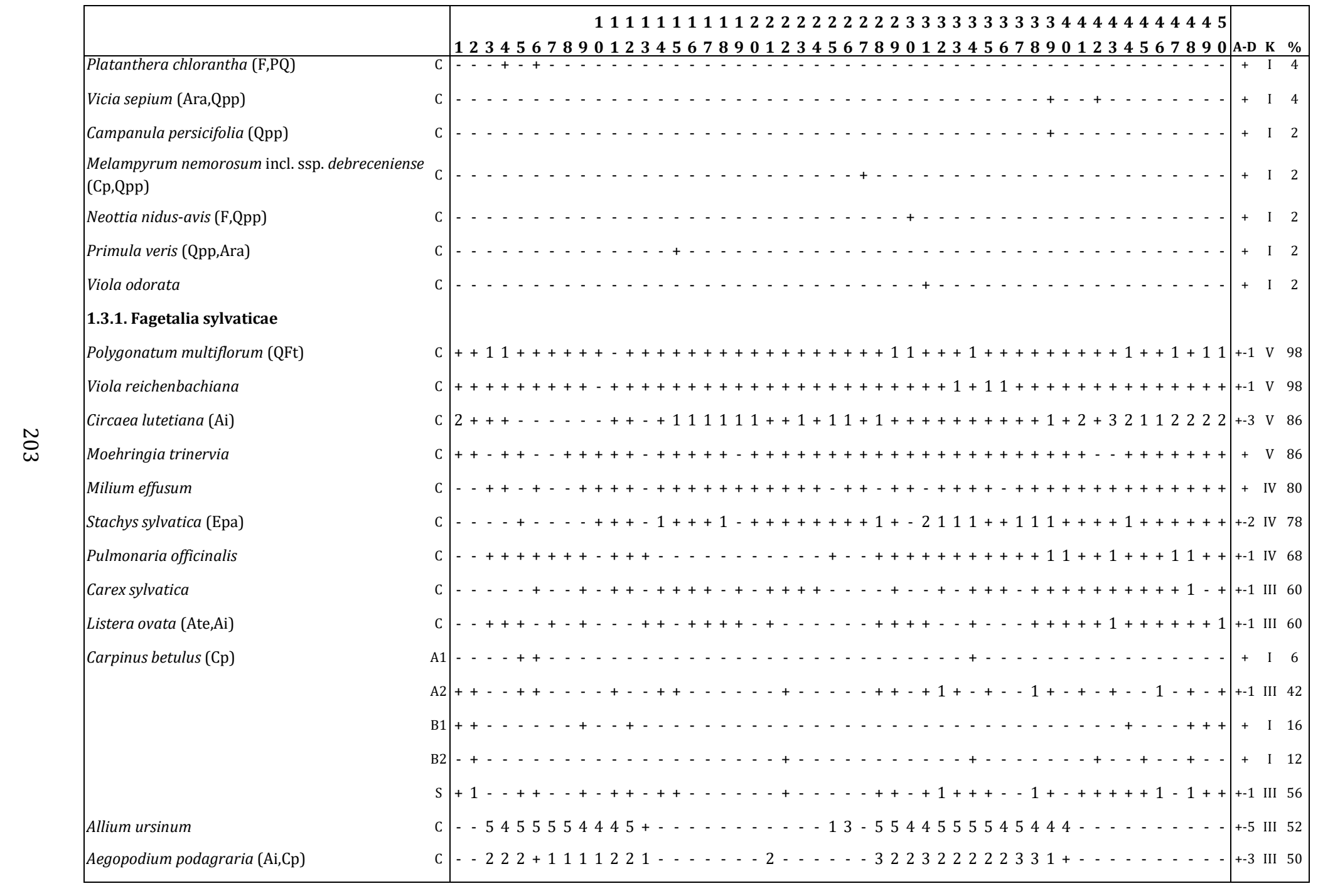




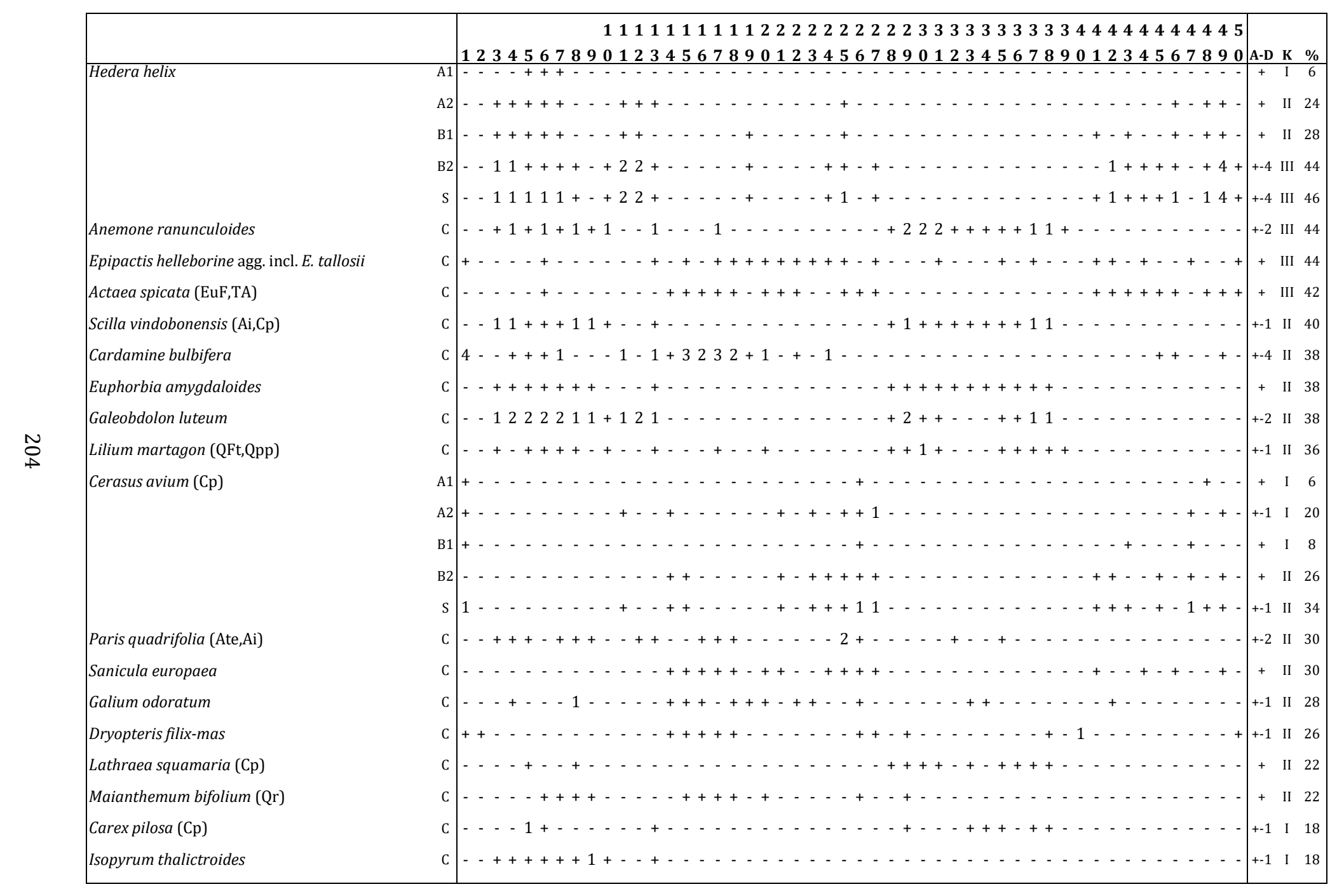




\begin{tabular}{|c|c|c|c|}
\hline & & $\begin{array}{r}11111111112222222222333333333344444444445 \\
12345678901234567890123456789012345678901234567890\end{array}$ & \\
\hline Ranunculus cassubicus & $\mathrm{C}$ & 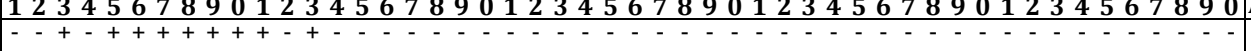 & 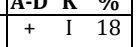 \\
\hline Chaerophyllum aromaticum (FiC) & $\mathrm{c}$ & 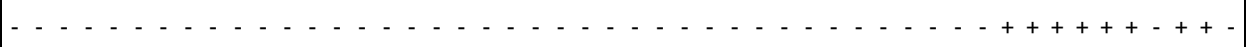 & +116 \\
\hline Corydalis cava & $\mathrm{c}$ & 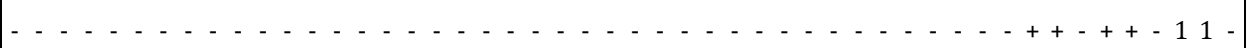 & \\
\hline \multirow[t]{5}{*}{ Acer platanoides (TA) } & $\mathrm{A} 1$ & 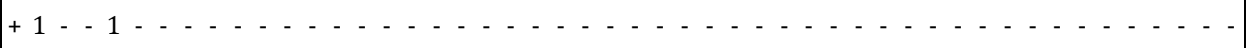 & \\
\hline & $\mathrm{A} 2$ & 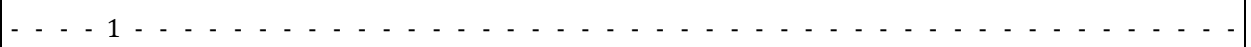 & $1 \quad 1 \quad 2$ \\
\hline & B1 & 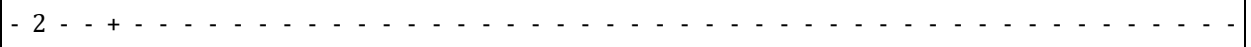 & +-2 I $\quad 4$ \\
\hline & в2 & 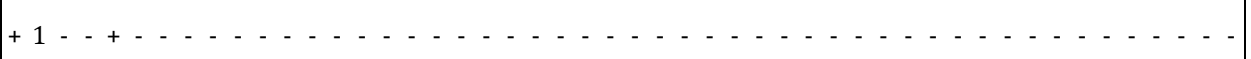 & +-1 I 6 \\
\hline & $\mathrm{s}$ & 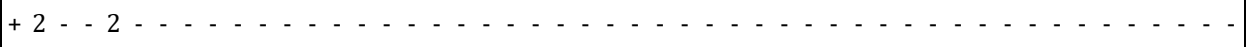 & +-2 $1 \mathrm{I} \quad 6$ \\
\hline Asarum europaeum & $\mathrm{c}$ & 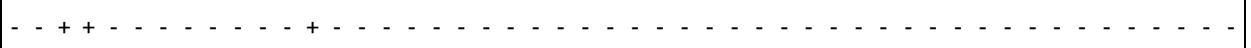 & +16 \\
\hline Athyrium filix-femina (Qr,VP) & $\mathrm{c}$ & 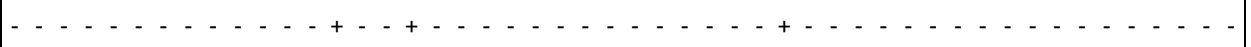 & +16 \\
\hline Lathyrus vernus & $\mathrm{c}$ & 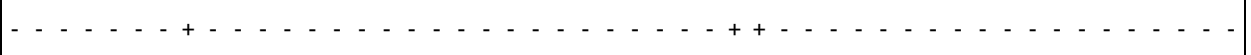 & +16 \\
\hline Mercurialis perennis & $\mathrm{c}$ & 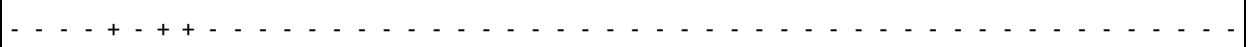 & +16 \\
\hline \multirow[t]{4}{*}{ Acer pseudo-platanus (TA) } & A1 & 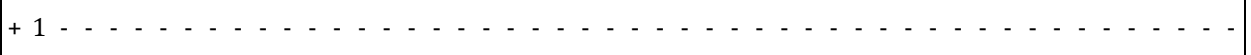 & $+-1 \quad 1 \quad 4$ \\
\hline & A 2 & 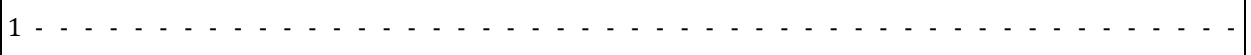 & $\begin{array}{lll}1 & 1 & 2\end{array}$ \\
\hline & в2 & 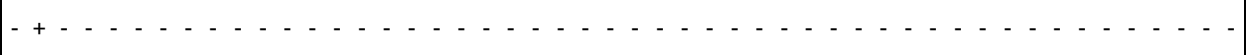 & +12 \\
\hline & & $111,1 n$ & $1 \quad 1 \quad 4$ \\
\hline Salvia glutinosa & c & 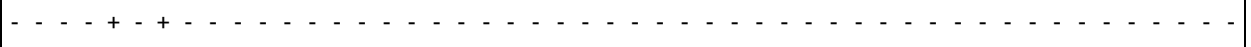 & +14 \\
\hline Cerastium sylvaticum (Ai) & $\mathrm{c}$ & 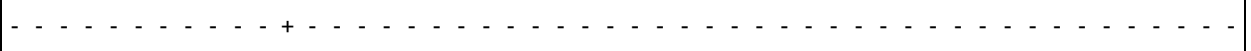 & +12 \\
\hline Stellaria holostea (Cp) & $\mathrm{c}$ & 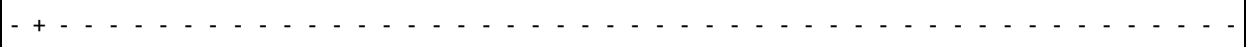 & +12 \\
\hline Ulmus glabra (TA) & B1 & $\begin{array}{l} \\
n_{1}\end{array}$ & +12 \\
\hline \multicolumn{4}{|l|}{ 1.3.1.1. Alnion incanae } \\
\hline Fraxinus angustifolia ssp. danubialis (Ate) & A1 & $--24441324+3431443322233123433234233434443+-2111-21+4-1$ & +-4 V 90 \\
\hline & & $+-22-+11 \ldots-2-111131111 \ldots+\cdots-1-2-+122111111+\cdots 1$ & +-3 III 54 \\
\hline & в1 & $+1-++++++1-+++++++11111212+11+-1+--1-++212+111-++$ & +-2 IV 76 \\
\hline & в2 & $+++++++++++++21+111122+2112+1+1+++1-111++++1+11+21$ & +-2 v 92 \\
\hline & $\mathrm{s}$ & $1133541324+3431553322442344423423343543113222222422$ & +-5 V 10 \\
\hline
\end{tabular}




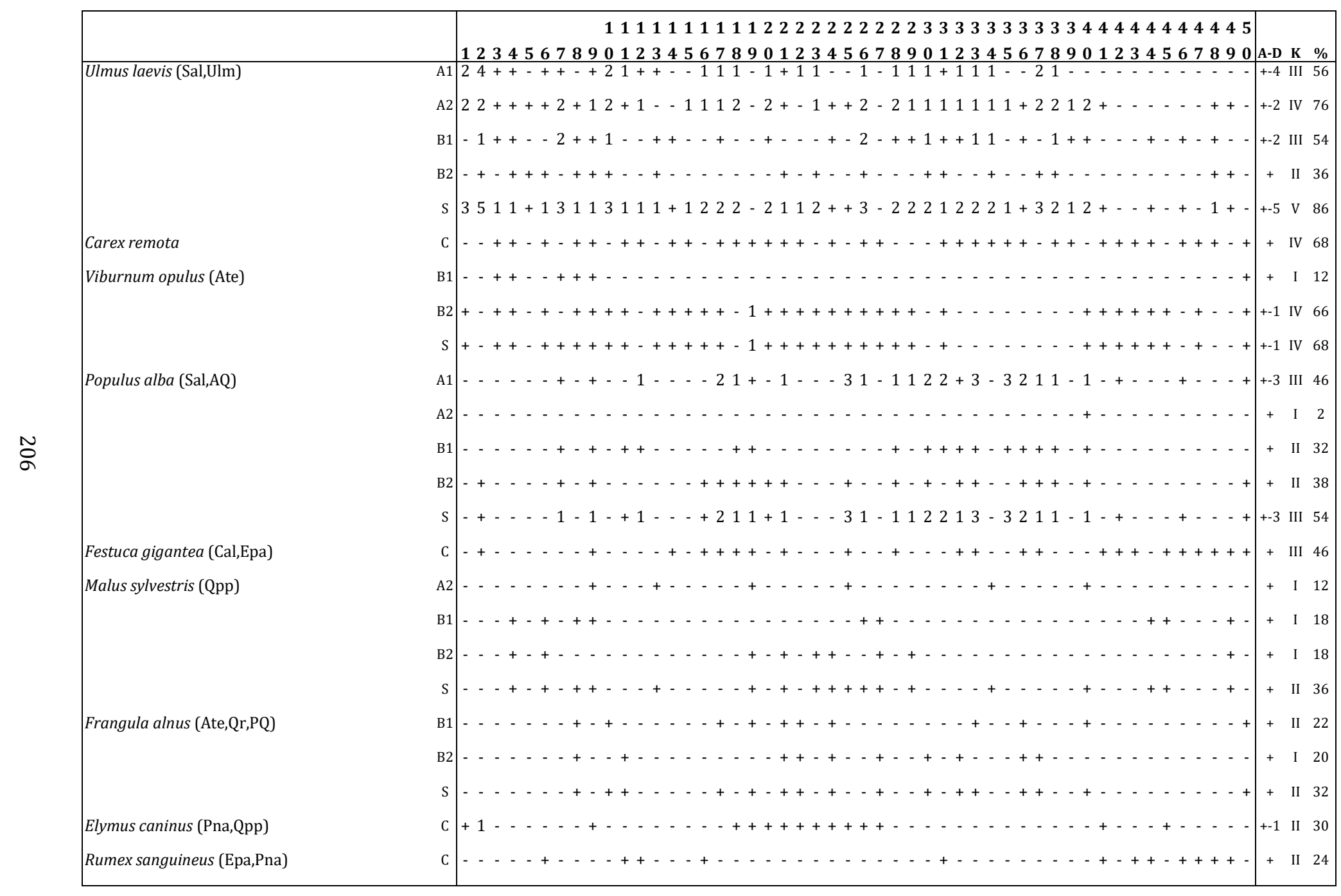




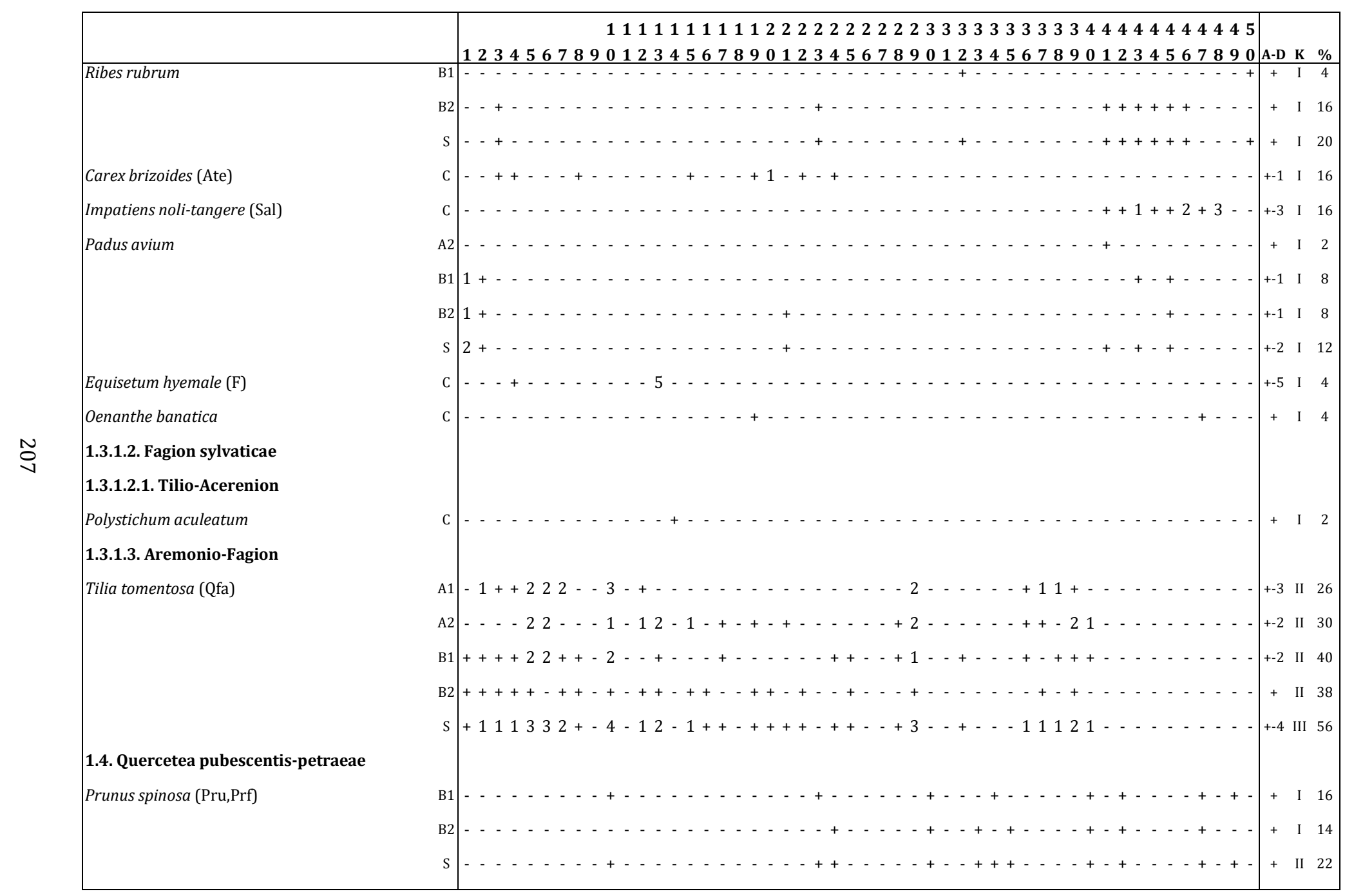




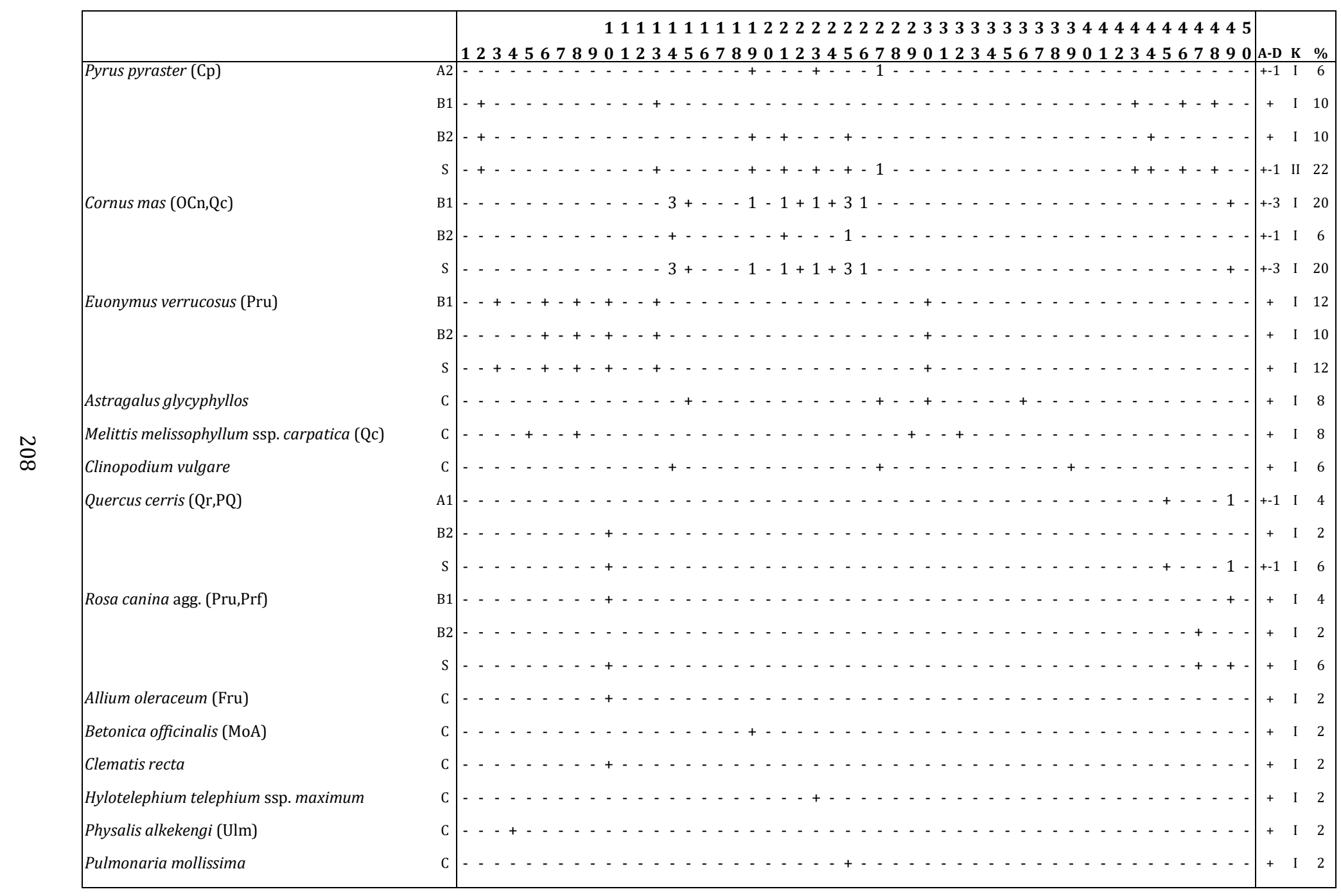




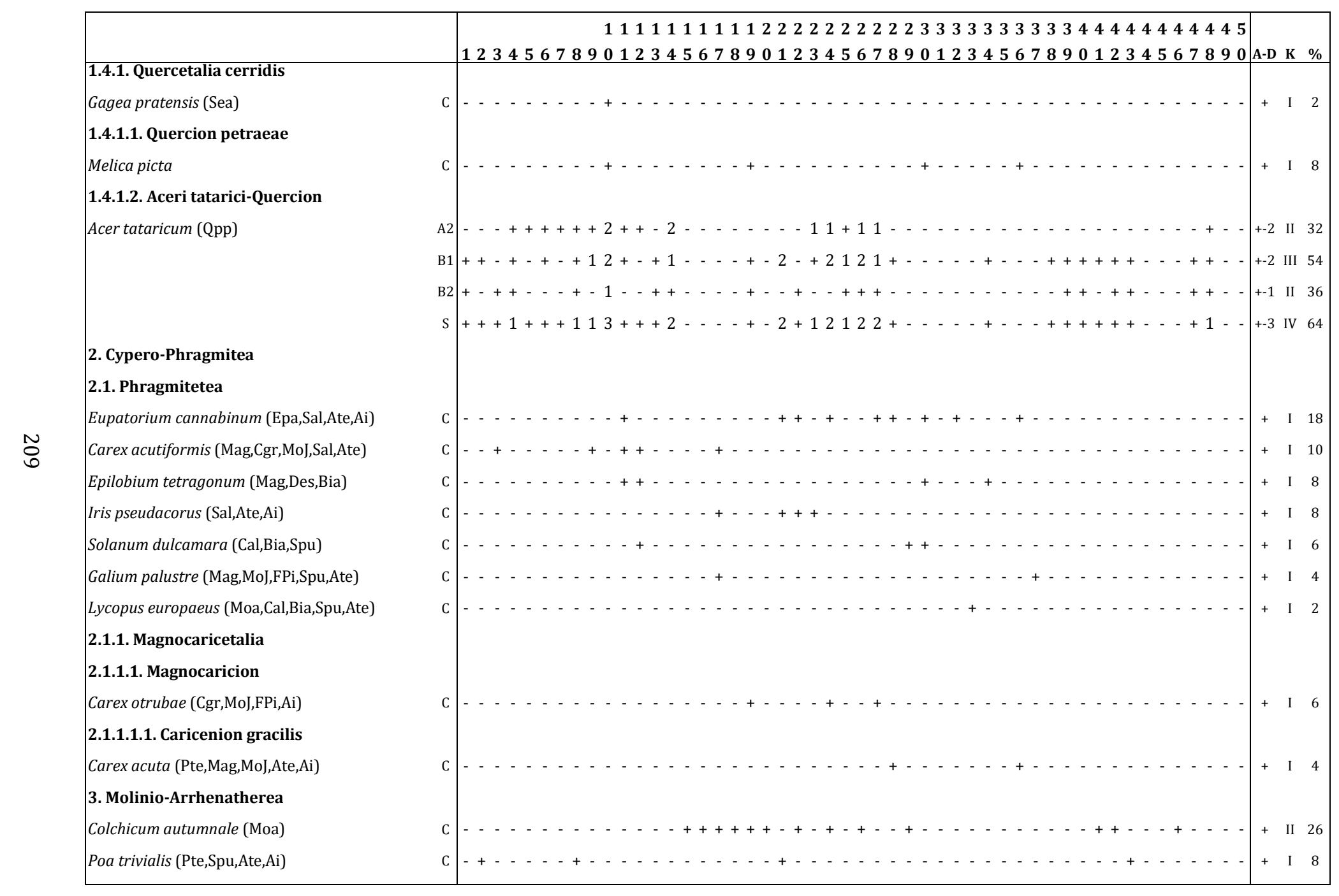




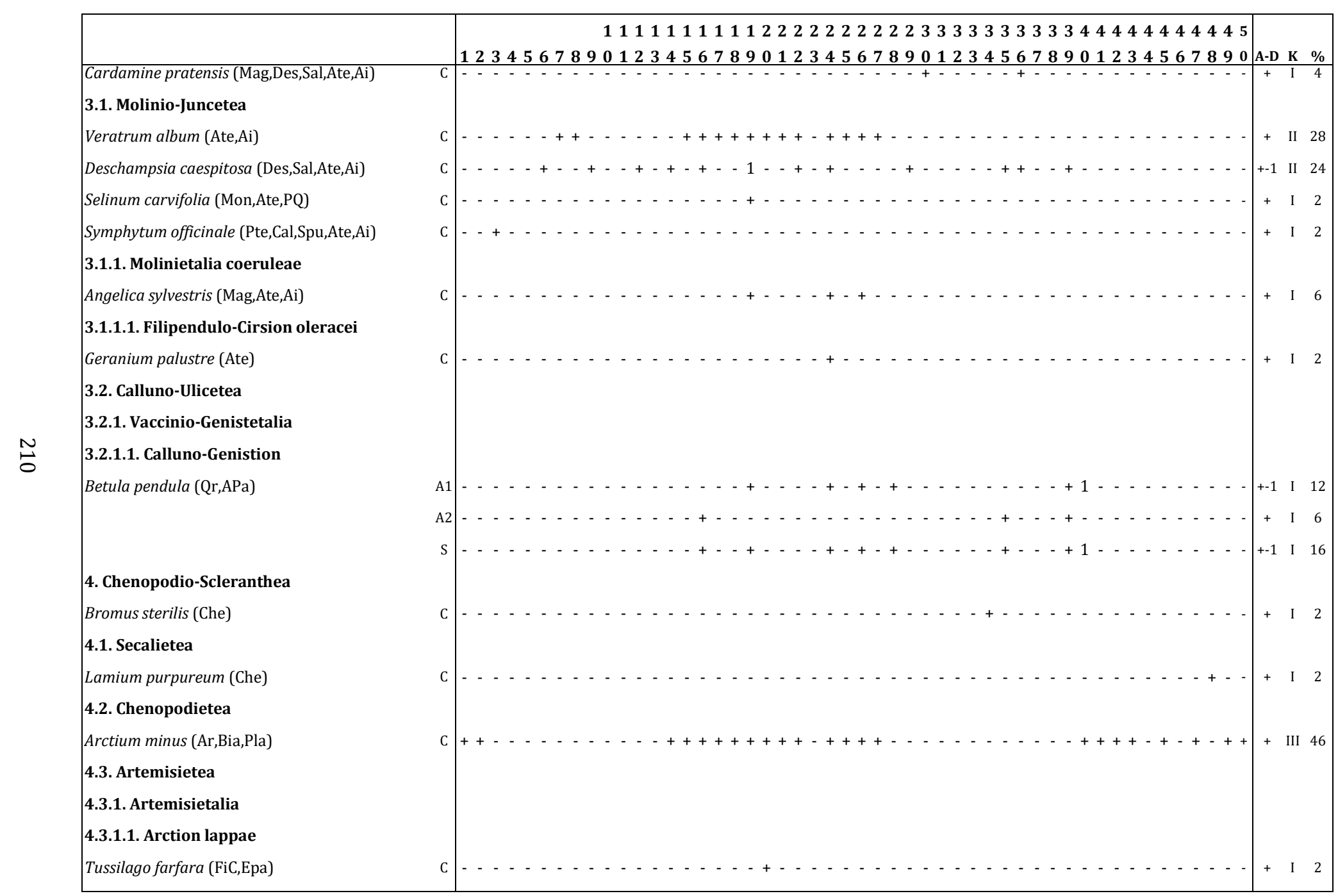




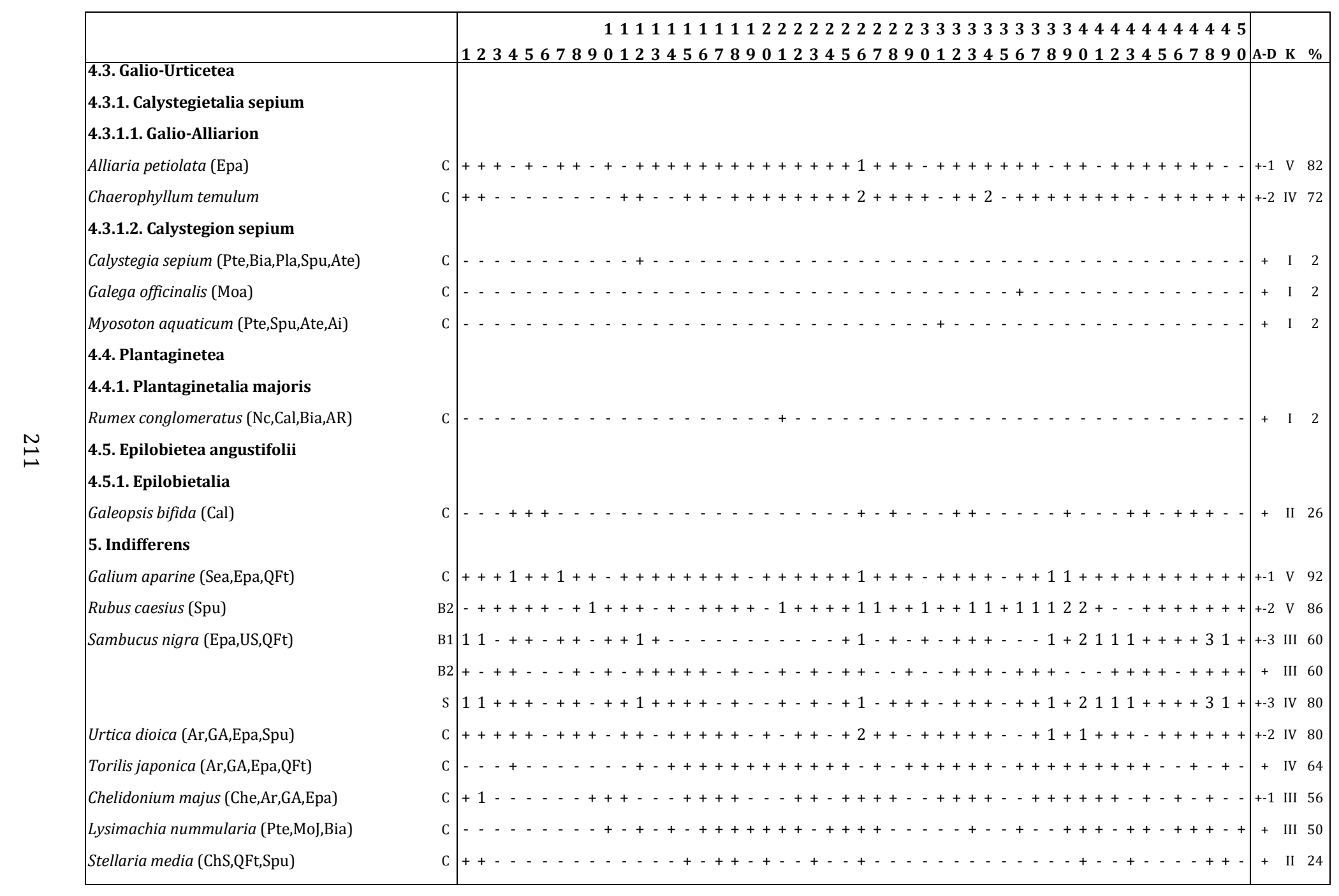




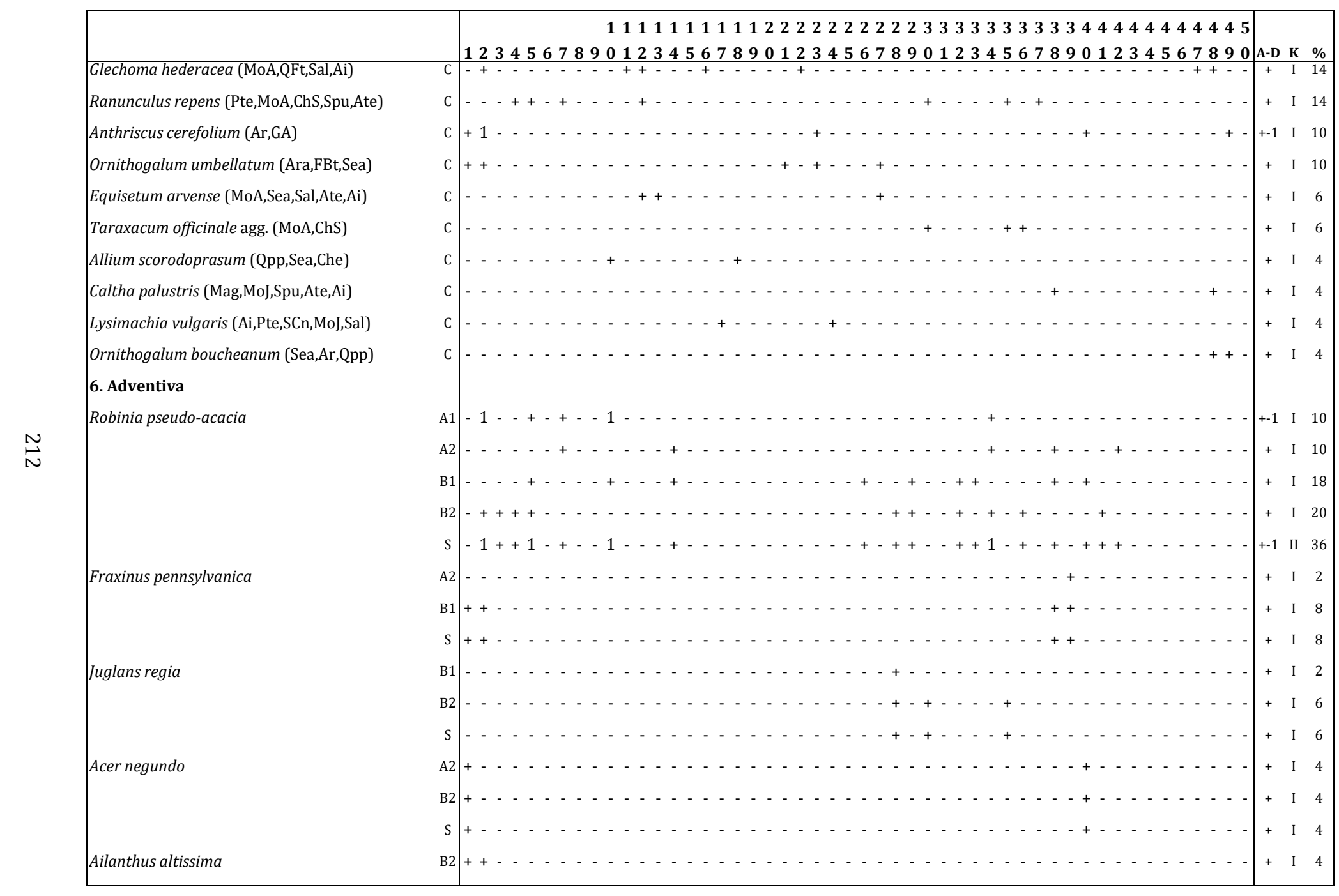




\begin{tabular}{|c|c|c|c|}
\hline & & $\begin{array}{r}111111111122222222222333333333344444444445 \\
12345678901234567890123456789012345678901234567890\end{array}$ & \\
\hline Stenactis annua & $\mathrm{C}$ & 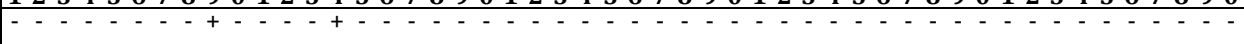 & $+\mathrm{I} 4$ \\
\hline Juglans nigra & A1 & -1 & $+\mathrm{I} 2$ \\
\hline Padus serotina & B2 & $+\cdots$ & $+\mathrm{I} 2$ \\
\hline Parthenocissus inserta & В2 & -1 & $+\mathrm{I} 2$ \\
\hline Quercus rubra & B2 & + $\ldots \ldots$ & $+\mathrm{I} 2$ \\
\hline
\end{tabular}


4. táblázat. Felvételi adatok az 3. táblázathoz (Keleti-Nyírség) / Table 2. Data of the relevés in Table 3. (E Nyírség)

\begin{tabular}{|c|c|c|c|c|c|c|c|c|c|c|c|c|c|c|c|c|c|c|c|c|c|c|c|c|c|}
\hline & 1 & 2 & 3 & 4 & 5 & 6 & 7 & 8 & 9 & 10 & 11 & 12 & 13 & 14 & 15 & 16 & 17 & 18 & 19 & 20 & 21 & 22 & 23 & 24 & 25 \\
\hline Minta felvételi sorszáma & 5961 & 5962 & 6282 & 6283 & 6285 & 6279 & 6280 & 6281 & 6284 & 6286 & 5963 & 5964 & 5965 & 6262 & 8841 & 8842 & 8843 & 8844 & 8846 & 8840 & 8847 & 8849 & 8848 & 8845 & 8835 \\
\hline Felvételi évszám 1. & 2004 & 2004 & 1979 & 1979 & 1979 & 1979 & 1979 & 1979 & 1979 & 1988 & 2004 & 2004 & 2004 & 1988 & 2003 & 2003 & 2003 & 2003 & 2003 & 2003 & 2003 & 2003 & 2003 & 2003 & 2003 \\
\hline Felvételi időpont 1. & 04.28 & 04.28 & 04.04 & 04.04 & 04.04 & 04.04 & 04.04 & 04.04 & 04.04 & 05.05 & 04.27 & 04.27 & 04.27 & 05.05 & 04.13 & 04.13 & 04.13 & 04.13 & 04.13 & 04.13 & 04.13 & 04.13 & 04.13 & 04.13 & 04.13 \\
\hline Felvételi évszám 2. & 2004 & 2004 & 1979 & 1979 & 1979 & 1979 & 1979 & 1979 & 1979 & 1988 & 2004 & 2004 & 2004 & 1988 & 2003 & 2003 & 2003 & 2003 & 2003 & 2003 & 2003 & 2003 & 2003 & 2003 & 2003 \\
\hline Felvételi időpont 2. & 06.24 & 06.24 & 06.21 & 06.21 & 06.21 & 06.21 & 06.21 & 06.21 & 06.21 & 08.19 & 06.24 & 06.24 & 06.24 & 08.19 & 07.16 & 07.16 & 07.16 & 07.16 & 07.16 & 07.16 & 07.16 & 07.16 & 07.16 & 07.16 & 07.19 \\
\hline Tengerszint feletti magasság (m) & 150 & 150 & 130 & 130 & 130 & 130 & 130 & 130 & 130 & 126 & 130 & 130 & 130 & 134 & 134 & 134 & 134 & 134 & 134 & 134 & 134 & 134 & 134 & 134 & 134 \\
\hline Kitettség & - & - & - & - & - & - & - & - & - & - & - & - & - & - & - & - & - & - & - & - & - & - & - & - & - \\
\hline Felső lombkoronaszint borítása (\%) & 70 & 70 & 80 & 75 & 75 & 80 & 75 & 70 & 75 & 80 & 80 & 75 & 80 & 70 & 65 & 70 & 70 & 70 & 80 & 75 & 75 & 70 & 75 & 70 & 70 \\
\hline Alsó lombkoronaszint borítása (\%) & 25 & 25 & 35 & 35 & 35 & 30 & 35 & 40 & 30 & 40 & 40 & 40 & 25 & 50 & 40 & 40 & 50 & 40 & 35 & 40 & 30 & 50 & 30 & 40 & 5 \\
\hline Cserjeszint borítása (\%) & 10 & 30 & 50 & 40 & 50 & 40 & 50 & 45 & 45 & 50 & 35 & 40 & 40 & 60 & 70 & 75 & 65 & 70 & 40 & 50 & 50 & 60 & 50 & 50 & 80 \\
\hline Újulat borítása (\%) & 5 & 5 & 5 & 5 & 1 & 1 & 1 & 1 & 2 & 5 & 20 & 15 & 1 & 1 & 10 & 5 & 1 & 5 & 10 & 5 & 25 & 10 & 1 & 10 & 10 \\
\hline Gyepszint borítása (\%) & 90 & 15 & 95 & 90 & 100 & 100 & 100 & 95 & 100 & 75 & 95 & 90 & 90 & 50 & 40 & 40 & 60 & 20 & 70 & 40 & 40 & 50 & 50 & 40 & 70 \\
\hline Felső lombkoronaszint magassága (m) & 22 & 20 & 28 & 26 & 28 & 26 & 26 & 26 & 28 & 25 & 28 & 28 & 28 & 28 & 30 & 30 & 30 & 30 & 30 & 30 & 30 & 30 & 30 & 30 & 30 \\
\hline Alsó lombkoronaszint magassága (m) & 16 & 15 & 14 & 14 & 15 & 14 & 14 & 12 & 12 & 15 & 20 & 18 & 15 & 10 & 16 & 16 & 16 & 18 & 18 & 16 & 17 & 12 & 16 & 17 & 12 \\
\hline Cserjeszint magassága $(\mathrm{cm})$ & 2 & 2 & 3 & 2,5 & 3 & 2,5 & 3 & 2,5 & 3 & 4 & 2,5 & 2,5 & 2,5 & 4 & 5 & 5 & 4 & 4 & 3 & 3,5 & 3 & 4 & 3 & 3 & 3 \\
\hline Átlagos törzsátmérő (cm) & 40 & 35 & 50 & 50 & 50 & 50 & 45 & 50 & 50 & 45 & 50 & 45 & 55 & 45 & 70 & 70 & 75 & 70 & 70 & 75 & 70 & 70 & 70 & 75 & 70 \\
\hline Felvételi terület nagysága $\left(\mathrm{m}^{2}\right)$ & 1200 & 1200 & 1600 & 1600 & 1600 & 1600 & 1600 & 1600 & 1600 & 1600 & 1200 & 1600 & 1600 & 1600 & 1600 & 1600 & 1600 & 1600 & 1600 & 1600 & 1600 & 1600 & 1600 & 1600 & 1200 \\
\hline
\end{tabular}


$\begin{array}{lllllllllllllllllllllllll}26 & 27 & 28 & 29 & 30 & 31 & 32 & 33 & 34 & 35 & 36 & 37 & 38 & 39 & 40 & 41 & 42 & 43 & 44 & 45 & 46 & 47 & 48 & 49 & 50\end{array}$

Minta felvételi sorszáma

62988832628762916292629362946297629562966289629062885957595912627126281263012632126261262912720127211272212719

Felvételi évszám 1.

2003200319941994199419941994199419941994199419941994200420042004200420042004200420042005200520052005

Felvételi időpont 1 .

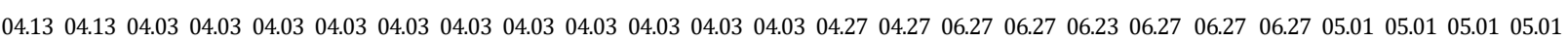

Felvételi évszám 2.

2003200319941994199419941994199419941994199419941994200420042005200520052005200520052005200520052005

Felvételi időpont 2.

07.19 07.19 07.01 07.0107 .0107 .0107 .0107 .0107 .0107 .0107 .0107 .0107 .0106 .2306 .2305 .0105 .0105 .0105 .0105 .0105 .0108 .1908 .1908 .1908 .19

Tengerszint feletti magasság $(\mathrm{m})$

$\begin{array}{lllllllllllllllllllllllll}134 & 134 & 126 & 126 & 126 & 126 & 126 & 126 & 126 & 126 & 126 & 126 & 126 & 126 & 126 & 116 & 116 & 116 & 116 & 116 & 116 & 116 & 116 & 116 & 116\end{array}$

Kitettség

Felső lombkoronaszint borítása (\%) - $\quad-\quad-\quad-$

Alsó lombkoronaszint borítása (\%)

Cserjeszint borítása (\%)

$\begin{array}{llllllllllllllllllllllllll}70 & 60 & 50 & 70 & 60 & 50 & 40 & 40 & 40 & 50 & 30 & 25 & 70 & 40 & 40 & 80 & 70 & 75 & 80 & 80 & 80 & 50 & 75 & 60 & 70\end{array}$

Újulat borítása (\%)

$\begin{array}{llllllllllllllllllllllllll}5 & 35 & 1 & 3 & 5 & 3 & 1 & 5 & 5 & 3 & 5 & 5 & 5 & 15 & 25 & 1 & 3 & 2 & 3 & 10 & 5 & 5 & 1 & 70 & 10\end{array}$

Gyepszint borítása (\%)

$\begin{array}{lllllllllllllllllllllllll}80 & 40 & 95 & 90 & 75 & 80 & 100 & 100 & 100 & 100 & 75 & 100 & 95 & 75 & 85 & 60 & 70 & 85 & 60 & 70 & 70 & 90 & 85 & 75 & 60\end{array}$

Felső lombkoronaszint magassága (m) $28 \begin{array}{llllllllllllllllllllllllll} & 27 & 26 & 22 & 20 & 28 & 27 & 28 & 30 & 28 & 22 & 22 & 28 & 30 & 30 & 30 & 30 & 28 & 30 & 30 & 30 & 30 & 32 & 32 & 32\end{array}$

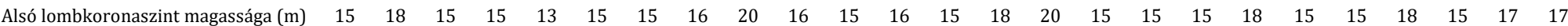
Cserjeszint magassága (cm)

Átlagos törzsátméró $(\mathrm{cm})$

Felvételi terület nagysága $\left(\mathrm{m}^{2}\right)$

1600160016001600160016001600160016001600160016001600120016001600160016001600160016001600160016001600 Hely: 1-2: Nyírvasvári „Csonkás-erdő”; 3-13: Bátorliget „Veres-folyás”; 14-27: Bátorliget „Fényi-erdő”; 28-40: Terem „Nagyfenék”; 41-50: Mérk „Vadas-kert”. Alapkőzet: 1-50: homok. Talaj: 150: Öntés erdőtalaj. Felvételt készítette: 1-10, 14, 25-38: KeveY (ined.); 11-13, 15-24, 39-40: KevEY \& PAPP (ined.); 41-50: KevEY, LendVAI \& PAPP (ined.) 
KEVEY et al. (2017) - Kitaibelia 22 (1): 179-220.

5. táblázat. Karakterfajok aránya / Table 5. Percentage of characteristic species of various syntaxa

\begin{tabular}{|c|c|c|c|c|}
\hline \multirow{2}{*}{ Szüntaxonok } & \multicolumn{2}{|c|}{ Csoportrészesedés } & \multicolumn{2}{|c|}{ Csoporttömeg } \\
\hline & $\mathrm{Ny}$ & $\mathbf{K}$ & $\mathrm{Ny}$ & $\mathbf{K}$ \\
\hline Querco-Fagea & 0,0 & 0,0 & 0,0 & 0,0 \\
\hline Salicetea purpureae & 0,0 & 0,0 & 0,0 & 0,0 \\
\hline Salicetalia purpureae & 1,4 & 1,3 & 0,4 & 0,4 \\
\hline Salicion albae & 1,7 & 1,7 & 1,6 & 2,0 \\
\hline Populenion nigro-albae & 0,8 & 0,3 & 0,1 & 0,0 \\
\hline Salicion albae s.l. & 2,5 & 2,0 & 1,7 & 2,0 \\
\hline Salicetalia purpureae s.l. & 3,9 & 3,3 & 2,1 & 2,4 \\
\hline Salicetea purpureae s.l. & 3,9 & 3,3 & 2,1 & 2,4 \\
\hline Alnetea glutinosae & 0,0 & 0,0 & 0,0 & 0,0 \\
\hline Alnetalia glutinosae & 1,9 & 2,9 & 4,9 & 6,7 \\
\hline Alnetea glutinosae s.l. & 1,9 & 2,9 & 4,9 & 6,7 \\
\hline Querco-Fagetea & 19,7 & 19,5 & 27,4 & 22,0 \\
\hline Fagetalia sylvaticae & 11,6 & 20,6 & 11,0 & 21,2 \\
\hline Alnion incanae & 7,4 & 8,7 & 12,8 & 14,3 \\
\hline Ulmenion & 1,3 & 1,2 & 1,9 & 1,6 \\
\hline Alnion incanae s.l. & 8,7 & 9,9 & 14,7 & 15,9 \\
\hline Fagion sylvaticae & 0,0 & 0,0 & 0,0 & 0,0 \\
\hline Eu-Fagenion & 0,1 & 0,2 & 0,0 & 0,0 \\
\hline Carpinenion betuli & 3,8 & 4,1 & 5,8 & 5,2 \\
\hline Tilio-Acerenion & 0,6 & 0,4 & 0,7 & 0,4 \\
\hline Fagion sylvaticae s.l. & 4,5 & 5,0 & 6,5 & 6,0 \\
\hline Aremonio-Fagion & 0,4 & 0,5 & 0,6 & 0,9 \\
\hline Fagetalia sylvaticae s.l. & 25,2 & 35,8 & 32,8 & 43,7 \\
\hline Quercetalia roboris & 0,2 & 0,7 & 0,0 & 0,1 \\
\hline Querco-Fagetea s.l. & 45,1 & 55,9 & 60,2 & 65,7 \\
\hline Quercetea pubescentis-petraeae & 15,7 & 13,4 & 20,5 & 18,9 \\
\hline Orno-Cotinetalia & 0,0 & 0,0 & 0,0 & 0,0 \\
\hline Orno-Cotinion & 0,0 & 0,1 & 0,0 & 0,2 \\
\hline Orno-Cotinetalia s.l. & 0,0 & 0,1 & 0,0 & 0,2 \\
\hline Quercetalia cerridis & 0,5 & 0,3 & 0,1 & 0,3 \\
\hline Quercion farnetto & 0,4 & 0,5 & 0,6 & 0,9 \\
\hline Quercion petraeae & 0,0 & 0,1 & 0,0 & 0,0 \\
\hline Aceri tatarici-Quercion & 0,2 & 0,9 & 0,8 & 1,0 \\
\hline Quercetalia cerridis s.l. & 1,1 & 1,8 & 1,5 & 2,2 \\
\hline Prunetalia spinosae & 0,6 & 0,4 & 0,1 & 0,0 \\
\hline Berberidion & 0,0 & 0,1 & 0,0 & 0,0 \\
\hline Prunion fruticosae & 0,4 & 0,2 & 0,0 & 0,0 \\
\hline Prunetalia spinosae s.l. & 1,0 & 0,7 & 0,1 & 0,0 \\
\hline Quercetea pubescentis-petraeae s.l. & 17,8 & 15,9 & 22,1 & 21,3 \\
\hline Querco-Fagea s.l. & 68,7 & 78,0 & 89,3 & 96,1 \\
\hline
\end{tabular}


KEVEY et al. (2017) - Kitaibelia 22 (1): 179-220.

\begin{tabular}{|c|c|c|c|c|}
\hline \multirow{2}{*}{ Szüntaxonok } & \multicolumn{2}{|c|}{ Csoportrészesedés } & \multicolumn{2}{|c|}{ Csoporttömeg } \\
\hline & $\mathrm{Ny}$ & $\mathbf{K}$ & $\mathrm{Ny}$ & $\mathbf{K}$ \\
\hline Abieti-Piceea & 0,0 & 0,1 & 0,0 & 0,0 \\
\hline Vaccinio-Piceetea & 0,0 & 0,1 & 0,0 & 0,0 \\
\hline Pino-Quercetalia & 0,0 & 0,0 & 0,0 & 0,0 \\
\hline Pino-Quercion & 0,1 & 0,2 & 0,0 & 0,0 \\
\hline Pino-Quercetalia s.l. & 0,1 & 0,2 & 0,0 & 0,0 \\
\hline Vaccinio-Piceetea s.l. & 0,1 & 0,3 & 0,0 & 0,0 \\
\hline Abieti-Piceea s.l. & 0,1 & 0,4 & 0,0 & 0,0 \\
\hline Cypero-Phragmitea & 0,0 & 0,0 & 0,0 & 0,0 \\
\hline Phragmitetea & 0,3 & 0,5 & 0,0 & 0,1 \\
\hline Magnocaricetalia & 0,0 & 0,0 & 0,0 & 0,0 \\
\hline Magnocaricion & 0,1 & 0,2 & 0,0 & 0,0 \\
\hline Caricenion gracilis & 0,1 & 0,1 & 0,0 & 0,0 \\
\hline Magnocaricion s.l. & 0,2 & 0,3 & 0,0 & 0,0 \\
\hline Magnocaricetalia s.l. & 0,2 & 0,3 & 0,0 & 0,0 \\
\hline Phragmitetea s.l. & 0,5 & 0,8 & 0,0 & 0,1 \\
\hline Cypero-Phragmitea s.l. & 0,5 & 0,8 & 0,0 & 0,1 \\
\hline Molinio-Arrhenatherea & 0,5 & 1,6 & 0,1 & 0,2 \\
\hline Molinio-Juncetea & 0,3 & 0,6 & 0,0 & 0,1 \\
\hline Molinietalia coeruleae & 0,2 & 0,3 & 0,0 & 0,0 \\
\hline Deschampsion caespitosae & 0,1 & 0,1 & 0,0 & 0,0 \\
\hline Filipendulo-Cirsion oleracei & 0,0 & 0,2 & 0,0 & 0,0 \\
\hline Molinietalia coeruleae s.l. & 0,3 & 0,6 & 0,0 & 0,0 \\
\hline Molinio-Juncetea s.l. & 0,6 & 1,2 & 0,0 & 0,1 \\
\hline Arrhenatheretea & 0,0 & 0,0 & 0,0 & 0,0 \\
\hline Arrhenatheretalia & 0,6 & 0,2 & 0,1 & 0,0 \\
\hline Arrhenatherion elatioris & 0,1 & 0,0 & 0,0 & 0,0 \\
\hline Arrhenatheretalia s.l. & 0,7 & 0,2 & 0,1 & 0,0 \\
\hline Arrhenatheretea s.l. & 0,7 & 0,2 & 0,1 & 0,0 \\
\hline Nardo-Callunetea & 0,0 & 0,0 & 0,0 & 0,0 \\
\hline Nardetalia & 0,0 & 0,0 & 0,0 & 0,0 \\
\hline Nardo-Agrostion tenuis & 0,1 & 0,0 & 0,0 & 0,0 \\
\hline Nardetalia s.l. & 0,1 & 0,0 & 0,0 & 0,0 \\
\hline Nardo-Callunetea s.l. & 0,1 & 0,0 & 0,0 & 0,0 \\
\hline Calluno-Ulicetea & 0,0 & 0,0 & 0,0 & 0,0 \\
\hline Vaccinio-Genistetalia & 0,0 & 0,0 & 0,0 & 0,0 \\
\hline Calluno-Genistion & 0,0 & 0,1 & 0,0 & 0,0 \\
\hline Vaccinio-Genistetalia s.l. & 0,0 & 0,1 & 0,0 & 0,0 \\
\hline Calluno-Ulicetea s.l. & 0,0 & 0,1 & 0,0 & 0,0 \\
\hline Molinio-Arrhenatherea s.l. & 1,9 & 3,1 & 0,2 & 0,3 \\
\hline
\end{tabular}


KEVEY et al. (2017) - Kitaibelia 22 (1): 179-220.

\begin{tabular}{|c|c|c|c|c|}
\hline \multirow{2}{*}{ Szüntaxonok } & \multicolumn{2}{|c|}{ Csoportrészesedés } & \multicolumn{2}{|c|}{ Csoporttömeg } \\
\hline & $\mathrm{Ny}$ & $\mathbf{K}$ & $\mathrm{Ny}$ & $\mathbf{K}$ \\
\hline Festuco-Bromea & 0,0 & 0,0 & 0,0 & 0,0 \\
\hline Festuco-Brometea & 0,2 & 0,0 & 0,0 & 0,0 \\
\hline Festucetalia valesiacae & 0,2 & 0,0 & 0,0 & 0,0 \\
\hline Festucion rupicolae & 0,1 & 0,0 & 0,0 & 0,0 \\
\hline Festucetalia valesiacae s.l. & 0,3 & 0,0 & 0,0 & 0,0 \\
\hline Festuco-Brometea s.l. & 0,5 & 0,0 & 0,0 & 0,0 \\
\hline Festuco-Bromea s.l. & 0,5 & 0,0 & 0,0 & 0,0 \\
\hline Chenopodio-Scleranthea & 0,6 & 0,2 & 0,1 & 0,0 \\
\hline Secalietea & 1,6 & 0,5 & 0,2 & 0,1 \\
\hline Chenopodietea & 0,9 & 0,4 & 0,1 & 0,0 \\
\hline Artemisietea & 0,0 & 0,0 & 0,0 & 0,0 \\
\hline Artemisietalia & 0,0 & 0,0 & 0,0 & 0,0 \\
\hline Arction lappae & 1,8 & 1,0 & 0,5 & 0,1 \\
\hline Artemisietalia s.l. & 1,8 & 1,0 & 0,5 & 0,1 \\
\hline Artemisietea s.l. & 1,8 & 1,0 & 0,5 & 0,1 \\
\hline Galio-Urticetea & 0,0 & 0,0 & 0,0 & 0,0 \\
\hline Calystegietalia sepium & 0,0 & 0,0 & 0,0 & 0,0 \\
\hline Galio-Alliarion & 4,6 & 3,6 & 1,9 & 0,6 \\
\hline Calystegion sepium & 1,5 & 1,0 & 0,1 & 0,1 \\
\hline Calystegietalia sepium s.l. & 6,1 & 4,6 & 2,0 & 0,7 \\
\hline Galio-Urticetea s.l. & 6,1 & 4,6 & 2,0 & 0,7 \\
\hline Bidentetea & 0,0 & 0,0 & 0,0 & 0,0 \\
\hline Bidentetalia & 0,5 & 0,5 & 0,1 & 0,1 \\
\hline Bidentetea s.l. & 0,5 & 0,5 & 0,1 & 0,1 \\
\hline Plantaginetea & 0,0 & 0,0 & 0,0 & 0,0 \\
\hline Plantaginetalia majoris & 0,4 & 0,2 & 0,0 & 0,0 \\
\hline Plantaginetea s.l. & 0,4 & 0,2 & 0,0 & 0,0 \\
\hline Epilobietea angustifolii & 0,0 & 0,0 & 0,0 & 0,0 \\
\hline Epilobietalia & 6,8 & 5,8 & 1,6 & 1,1 \\
\hline Epilobietea angustifolii s.l. & 6,8 & 5,8 & 1,6 & 1,1 \\
\hline Urtico-Sambucetea & 0,0 & 0,0 & 0,0 & 0,0 \\
\hline Sambucetalia & 0,0 & 0,0 & 0,0 & 0,0 \\
\hline Sambuco-Salicion capreae & 0,5 & 0,3 & 0,2 & 0,2 \\
\hline Sambucetalia s.l. & 0,5 & 0,3 & 0,2 & 0,2 \\
\hline Urtico-Sambucetea s.l. & 0,5 & 0,3 & 0,2 & 0,2 \\
\hline Chenopodio-Scleranthea s.l. & 19,2 & 13,5 & 4,8 & 2,3 \\
\hline Indifferens & 3,5 & 2,8 & 0,9 & 0,7 \\
\hline Adventiva & 5,7 & 1,2 & 4,6 & 0,2 \\
\hline
\end{tabular}

Ny: Nyugati-Nyírség (Kevey \& PAPP ined.: 25 felv.) K: Keleti-Nyírség (KeveY, LendVAI \& PAPP ined.: 50 felv.) 
Kevey et al. (2017) - Kitaibelia 22 (1): 179-220.

6. táblázat. Szociális magatartási típusok aránya

Table 6. Proportion of Social Behavior Types (SBT)

\begin{tabular}{|c|c|c|c|c|c|}
\hline \multirow{2}{*}{\multicolumn{2}{|c|}{ SBT }} & \multicolumn{2}{|c|}{ Csoportérszesedés } & \multicolumn{2}{|c|}{ Csoporttömeg } \\
\hline & & \multirow{2}{*}{$\begin{array}{c}\text { Ny } \\
4,1\end{array}$} & \multirow{2}{*}{$\frac{\mathbf{K}}{9,1}$} & \multirow{2}{*}{$\frac{\mathrm{Ny}}{2,9}$} & \multirow{2}{*}{$\begin{array}{c}\mathbf{K} \\
6,7\end{array}$} \\
\hline $\mathbf{S}$ & 6 & & & & \\
\hline Su & 10 & 0,0 & 0,0 & 0,0 & 0,0 \\
\hline $\mathrm{Sr}$ & 8 & 0,1 & 0,0 & 0,0 & 0,0 \\
\hline C & 5 & 9,7 & 14,3 & 41,4 & 47,1 \\
\hline $\mathrm{Cu}$ & 9 & 0,0 & 0,0 & 0,0 & 0,0 \\
\hline $\mathrm{Cr}$ & 7 & 0,0 & 0,0 & 0,0 & 0,0 \\
\hline $\mathbf{G}$ & 4 & 47,5 & 49,7 & 43,4 & 41,4 \\
\hline Gu & 8 & 0,0 & 0,0 & 0,0 & 0,0 \\
\hline Gr & 6 & 0,0 & 0,0 & 0,0 & 0,0 \\
\hline NP & 3 & 0,0 & 0,0 & 0,0 & 0,0 \\
\hline DT & 2 & 24,4 & 20,9 & 6,3 & 4,0 \\
\hline $\mathbf{w}$ & 1 & 8,2 & 4,6 & 1,3 & 0,6 \\
\hline I & -1 & 2,3 & 0,3 & 0,9 & 0,0 \\
\hline $\mathbf{A}$ & -1 & 0,6 & 0,0 & 0,1 & 0,0 \\
\hline RC & -2 & 0,0 & 0,1 & 0,0 & 0,0 \\
\hline AC & -3 & 3,2 & 0,9 & 3,7 & 0,2 \\
\hline \multicolumn{2}{|c|}{ Val } & 3,1 & 3,7 & 4,0 & 4,5 \\
\hline
\end{tabular}

Ny: Nyugati-Nyírség (KeVEY \& PAPP ined.: 25 felv.) K: Keleti-Nyírség (KEVEY, LENDVAI \& PAPP ined.: 50 felv.)

7. táblázat. Differenciális fajok / Table 7. List of differential species

\begin{tabular}{lcc}
\hline & Ny & K \\
\hline Konstans fajok & & \\
Elymus caninus & V & II \\
Arctium minus & V & III \\
Cucubalus baccifer & V & III \\
Veronica sublobata & V & III \\
Ajuga reptans & - & V \\
Viola reichenbachiana & I & V \\
Acer campestre & III & V \\
Fraxinus angustifolia ssp. danubialis & III & V \\
Polygonatum multiflorum & III & V \\
Ranunculus ficaria & III & V \\
Ulmus laevis & III & V \\
Szubkonstans fajok & & \\
Cerasus avium & IV & II \\
Galeopsis pubescens & IV & II \\
Polygonatum latifolium & IV & II \\
Acer tataricum & - & IV \\
Pulmonaria officinalis & I & IV \\
Carex remota & II & IV \\
Milium effusum & II & IV \\
Scrophularia nodosa & II & IV \\
Akcesszórikus fajok & & \\
Celtis occidentalis & III & - \\
Acer negundo & III & I \\
Gagea pratensis & III & I \\
\hline
\end{tabular}

\begin{tabular}{lcc}
\hline & Ny & K \\
\hline Ornithogalum boucheanum & III & I \\
Salvia glutinosa & III & I \\
Viola suavis s.l. & III & I \\
Actaea spicata & - & III \\
Allium ursinum & - & III \\
Carpinus betulus & - & III \\
Tilia cordata & - & III \\
Aegopodium podagraria & I & III \\
Anemone ranunculoides & I & III \\
Hedera helix & I & III \\
Listera ovata & I & III \\
Viola mirabilis & I & III \\
Szubakcesszórikus fajok & & \\
Anthriscus sylvestris & II & - \\
Arum orientale & II & - \\
Glechoma hirsuta & II & - \\
Impatiens parviflora & II & - \\
Lactuca quercina ssp. sagittata & II & - \\
Dryopteris filix-mas & - & II \\
Euphorbia amygdaloides & - & II \\
Galeobdolon luteum & - & II \\
Lathraea squamaria & - & II \\
Maianthemum bifolium & - & II \\
Paris quadrifolia & - & II \\
Staphylea pinnata & - & II \\
\hline Differenciális fajok száma & $\mathbf{1 8}$ & $\mathbf{2 8}$
\end{tabular}


8. táblázat. A Nyírség tölgy-kőris-szil ligeteinek védettsége Table 8. Conservation status of oak-ash-elm forests in the Nyírség

\begin{tabular}{|c|c|c|c|c|c|c|}
\hline & & 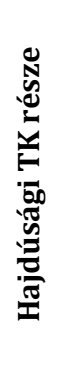 & 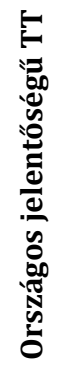 & 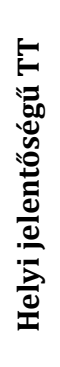 & 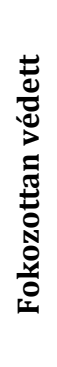 & 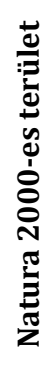 \\
\hline \multirow{2}{*}{ Bátorliget } & „Fényi-erdő” & - & $x$ & - & $x$ & $x$ \\
\hline & „Veres-folyás” & - & $x$ & - & $x$ & $x$ \\
\hline \multirow{4}{*}{ Debrecen } & „Halápi-erdő” & $x$ & - & - & $x$ & - \\
\hline & „Nagycsere” & $x$ & - & - & - & - \\
\hline & „Nagy-erdő” & - & $x$ & - & - & $x$ \\
\hline & „Monostori-erdő” & - & - & $x$ & - & $x$ \\
\hline Mérk & „Vadas-kert” & - & - & - & - & - \\
\hline Nyíradony & „Gúti-erdő" & $x$ & - & - & - & $x$ \\
\hline \multirow{2}{*}{ Nyírábrány } & „Kiskőrises” & $x$ & - & - & - & - \\
\hline & „Mogyorósi-erdő” & $x$ & - & - & - & $x$ \\
\hline Nyírvasvári & „Csonkás-erdő” & - & - & - & - & - \\
\hline Terem & „Nagyfenék” & - & - & - & - & $x$ \\
\hline Újfehértó & „Ángliusi-erdő" & - & - & - & - & - \\
\hline
\end{tabular}

